OPEN ACCESS

Edited by:

Casey Hoy,

Ohio State University, United States

Reviewed by:

Paolo D'Odorico,

University of California, Berkeley,

United States

Taiyang Zhong,

Nanjing University, China

*Correspondence:

Ebenezer Miezah Kwofie

emkwofie@uark.edu

Specialty section:

This article was submitted to

Social Movements, Institutions and

Governance,

a section of the journal

Frontiers in Sustainable Food Systems

Received: 06 March 2021

Accepted: 25 May 2021

Published: 27 July 2021

Citation:

Agyemang P and Kwofie EM (2021)

Response-to-Failure Analysis of Global Food System Initiatives: A

Resilience Perspective.

Front. Sustain. Food Syst. 5:676997.

doi: 10.3389/fsufs. 2021.676997

\section{Response-to-Failure Analysis of Global Food System Initiatives: A Resilience Perspective}

\author{
Prince Agyemang ${ }^{1,2}$ and Ebenezer Miezah Kwofie ${ }^{1 *}$ \\ ${ }^{1}$ Agri-Food Product and Process Sustainability and Resilience Research Program, Department of Biological and Agricultural \\ Engineering, University of Arkansas, Fayetteville, AR, United States, ${ }^{2}$ Abunde Sustainable Engineering Group, Buea, \\ Cameroon
}

International food system initiatives have led the efforts to combat the threats to global food security resulting from the failure of the current food systems. This study set out to investigate and assess the contributions of global food system initiatives in tackling the food system challenges. In assessing the food system initiatives, we develop a three-step methodology for Food System Initiative (FSI) selection and then conduct a qualitative evaluation using relevant indicators based on food system failure narratives. Furthermore, the authors synthesize present literature in the context of the extent to which coronavirus disease 2019 (COVID-19) pandemic has compounded food system challenges and, together with the response-to-failure analysis, recreate a resilient transformational framework, which will be an invaluable tool to FSI during and after the COVID-19 era, and guarantee we build back better. The findings show that while considerable effort is being made in addressing food system failures, the current COVID-19 pandemic has exacerbated the challenges and would require a paradigm shift not only in the implementation of conventional food system initiatives but also in the role of food system actors. The food system resilience framework presented provides useful pathway in expanding the understanding of the role of all key stakeholders and in identifying tipping points for building the desired resilience moving forward.

Keywords: resilient, framework, paradigm shift, food system initiatives, food system failure

\section{INTRODUCTION}

In the last few decades, there has been a surge of interest from international organizations, governments, industries, and cooperate bodies to implement initiatives that ensure the United Nations Agenda on food security and nutrition are met.

The support for this agenda began in the late 1990's through the launch of a globally agreed mandate, the Millennium Development Goals (MDGs), and then in 2015, it was followed by the Sustainable Development Goal (SDG number two), which advocates for "zero hunger." Although the global policy (MDGs) seemed to achieve its target, a broader understanding of the existing pathways to ensure food security was not accounted for. More importantly, the discovery of the multidimensionality (dimensions, time, and space) of the food system became aspects of increased importance. This led to a revision in priority indicators as well as additional indicators in championing SDG number two (Murray, 2015; Gil et al., 2019). 
Whereas some countries across the globe currently produce enough food to feed their citizens, others are not. The key players in the global food supply chain have an enabling environment (such as government subsidies, taxes, and regulations) to produce more and hence have access to a global environment to dictate the pattern of food trade. Yet, others with less financial muscle (minor players) to dictate the trade directions leave the poorest consumers in their country to food and nutrition insecurity. Aside from factors such as trade policy and market performance, other factors including infrastructural capacity contribute to this disparity.

According to the 2019 Food and Agriculture Organization's (FAO's) report on the global state of food security, close to two billion people experience severe food insecurity, well more than one billion people are overweight and just over 820 million people go hungry today, which threatens the achievability of the "Zero Hunger" target by 2030 (FAO, 2019). It is imperative to establish that this goal aims not only to "eradicate hunger," but also to "ensure access by all people across the United Nations member countries, to safe, nutritious, and sufficient food all year round" (SDG Target 2.1) and to "eradicate all forms of malnutrition" (SDG Target 2.2) (Bizikova et al., 2020).

Notwithstanding, within the research and policy development domain on food security and nutrition, numerous innovations to address food system challenges and policy intervention programs have been implemented to strengthen our food system. This is evidenced by the abundance of literature, reporting on initiatives, strategies, action plans, and on the current global status in combating hunger and improving nutrition (El Bilali et al., 2019). Despite these major efforts to eradicate hunger, the current food systems have fueled negative outcomes such as environmental degradation, biodiversity loss, excessive greenhouse gas emissions to which it accounts for $\sim 30 \%$ of the total global emissions (Macdiarmid et al., 2011; Vermeulen et al., 2012), and a staggering increased rate of persistent malnutrition and hunger (Beddington, 2011; FAO, 2014). More disturbingly, the failure of the food systems to provide balanced nutrition has been a significant root cause of many global illnesses, diseases, and inability to build immunity to infections (Mozaffarian, 2016; Kuyper et al., 2017).

To this end, the Food and Agricultural Organization in partnership with government and non-governmental bodies have launched key innovative initiatives and agendas including Climate Smart Agriculture (Venkatramanan and Shah, 2019), Regenerative Agriculture (Duncan, 2016), Agricultural intensification (Matson et al., 1997; Tscharntke et al., 2005), Precision farming (Auernhammer, 2001), and Circular Economy (Kirchherr et al., 2017) to drive the food system toward sustainability in the rural and periurban space. These agendas have promoted soil health, improved biodiversity, reduced cost in farm inputs, and, more importantly, delivered nutritious farm produce. Furthermore, they have provided knowledge, information, and expertise, which have boosted agriculture and the food system.

Similarly, food system transformational initiatives such as the Global Alliance for the Future of Food, UN Environment Programme food system initiative, Netherlands Food
Partnership, Food Action Alliance (FAA), Food System Dialogue, C40 Cities, Food System Network, and Food \& Business Knowledge Platform (F\&BKP), among others, have presented comprehensive solutions and strategies that support and speed up food transformation to feed 10 billion people by 2050 .

Moving beyond the unsustainability challenges identified in earlier paragraphs, the current coronavirus disease 2019 (COVID-19) pandemic has caused all stakeholders to reflect on the sustainability and resilience of the food system to this unprecedented shock (Devereux et al., 2020).While existing food system initiatives and programs considered shocks, such as climate change and natural disasters, and stresses, such as corruption and political instability, COVID-19 was unanticipated. As argued by Seekell et al. (2017), to sustainably ensure food security to the human population, the food system and, in particular, the supply chain must adapt to disruptions. However, this has not been the case, COVID-19 crisis has laid bare the overarching vulnerabilities within our global food system from a resilient perspective, stimulating the necessity to build back a better one (Galanakis, 2020). Some of these include restricted access to nutritious food at affordable prices and the collapse of small and medium food enterprises (Henry, 2020). Indirectly, COVID-19 has exposed diverse fragilities in the food system that were never envisioned. Perhaps, an increased emphasis on resilience of food system to buffer against external shocks and guarantee food security that does not elude the world's population is the key (Schipanski et al., 2016).

This challenge coupled with multiple concerns of food insecurity, malnutrition, and food inequality highlights the need to focus on a healthy, circular, and more efficient food system. Also, these trends reiterate the gap that exists in achieving SDG 2 and affirm that our current food system is failing us. The broad use of the term "food system failure" as discussed in the literature and mentioned in earlier paragraphs refers to "the inability of the current food system to provide the expected need to meet full societal well-being" (Rosin et al., 2013).

Taken together, the food system resilience is under continuous threat and therefore calls for a need to innovate key strategies, technologies, and robust systems on a large scale to simultaneously meet the world's growing food requirements, as well as staying within the planet's safe operating boundaries. This also calls for the need to evaluate our current actions and initiatives in addressing food system challenges to identify points of failures to develop pragmatic and robust routes to ensure a more resilient food system.

Considering the above gaps, this article provides insights into the contributions of global Food System Initiative (FSI) and potential partners within the global and regional landscape and identifies key donor landscape for healthy, diverse, and circular food systems. The authors evaluate the progress made by existing food system initiatives in addressing the current narratives of food system failure. To gain further understanding, the study synthesizes the results of the evaluation along with a map of the impact of COVID-19 on the food system, to the extent to which, we develop a novel pragmatic transformational framework for redesigning food system moving forward. Again, 
the authors extend the conventional literature reporting mindset to an innovative analytical mindset, thereby improving the efficiency of the information gathered. However, the evaluation and assessment of the impacts of initiatives by tracking indicators against predefined transformational goals are far from being able to achieve the desired change within our food system. The overall structure of the study takes the form of four sections including the introduction. In the second section, we present the methodology. Here, we (1) give an overview of the conceptual framework used in this study, (2) present the current perspectives of food system failure, (3) identify indicators and metric for assessing initiatives, and (4) develop a three-step methodology in selecting the initiatives. Subsequently, in Results and Discussion, we present the results of the study. Also, here, we (1) provide a brief description of selected food system initiative, (2) analyze the performance of these initiatives using the metrics developed, (3) map out the disruptions and impact of COVID-19 on the food system, and (4) present a reflective reconstruction of the food system based on the lessons learned. The final section gives a summary and critique of the findings of the study.

\section{METHODOLOGY}

\section{The Conceptual Framework for the Study}

Figure 1 displays the conceptual framework used in this study, which consists three main stages. In the first stage, the authors begin by discussing four distinct narratives on food system failure in the light of food insecurity, malnutrition, social inequality and inequity, and environmental degradation. There are certainly opportunities to explore the dimensions of food insecurity (availability, access, utilization, and stability) as distinct areas of failure; however, they do not holistically capture the different failures within the entire food system. The current failure narrative adopted in this study are reported in a large number of literatures and looks beyond issues of food security, which is but one of dimensions of food system challenges (FAO, 2016; Haddad et al., 2016; Beal et al., 2017).

Next, we move on to develop a methodology to select and qualitatively assess the efforts of existing global food system initiatives in tackling the challenges of the failure. The next stage of the study focuses on how the unprecedented shock, COVID-19, has impacted our current food system, laying bare the persistent failures. As displayed in Figure 1, COVID-19 has resulted in higher food insecurity, nutritional insecurity, food inequality, and environmental implications. These heightened implications on the existing narratives of food system failure are as a result of the lockdown, unemployment, trade restrictions, and closure of production systems associated with COVID-19 pandemic. As of the time this study was conducted, there has been little information in the literature discussing the impact of the pandemic on the environmental dimension of the food system, save for its implications on postharvest losses.

Because of the devastating impact of the COVID-19 pandemic, there is a consensus that our food system needs deep reforms and reconstruction. Others (Cattivelli and Rusciano, 2020; Shilomboleni, 2020) argue that the current initiative activities need to be intensified. Therefore, in the final stage of the conceptual framework, the authors present a novel food system transformation framework that can be used by food system initiatives to achieve their objectives and action plans in the context of a pandemic. The COVID-19 pandemic, like many other shocks, has forced significant changes in every fabric of the food system. Regardless of how the food system performs now, if it is unable to withstand any shock thrown at it, then that is a failure of the system. As a result, the ultimate objective of the framework is to achieve a resilience food system. To wit, circular economy [refers to reducing the amount of waste generated, reuse of food, byproduct and food waste, and nutrient recycling (Jurgilevich et al., 2016)] and sustainable manufacturing strategies would help build resilience to the vulnerabilities across the different dimensions. Although it has not reached a breaking point yet, all stakeholders including consumers, governments, and corporations alike concur that a resilience food system must deliver a nutritious and healthy diet, the corollary amounts to a failure of the food system. It is expedient to understand that transformational frameworks provide a route through which action plans of food system initiatives can be assessed and implemented successfully taking into account health, social inclusion and circularity, and planetary boundaries, covering farm-based, value chain, finance, policy, and market interventions.

\section{Food System Failure Analysis Metric Food System Failure Perspective}

As indicated previously, it is clear that our food system is failing. Several narratives have been reported in the literature, highlighting the inability of the current food system to meet the food security and malnutrition challenge (Rosin et al., 2013). The first dimension of the failure is captured as the inability to produce enough food to feed the global population. In this light, West et al. (2014) attempted to define leverage points that can provide enough calories to meet food-insecurity challenges for more than three billion people while addressing many environmental impacts. The second generally accepted dimension focuses on the nutritional gap that persists. Likewise, to this, Hawkes and Ruel (2011) demonstrated that food value chain concepts can be exploited to meet nutritional challenges. On the other hand, the challenge of social inequality and inequity has been frequently reported in the literature. This challenge was highlighted by Mooney (2017), who focused on the proportionate amount of the global population that continues to experience hunger and inappropriate allocation of power, which introduces food inequality and inequity in the food system. Following this further, D'Odorico et al. (2019) expounded on the inequality that exists in terms of the distribution of natural resource for agricultural production and in food availability due to economic potential and trade patterns.

While Amundson et al. (2015) helped distinguish the final challenge as the authors in his dissertation assessed the implications of human activities, especially agriculture on soil ecology and the recent global advances in understanding, and replenish it. Deductively, there exist four perspectives in discussing the issue regarding food system failure as 


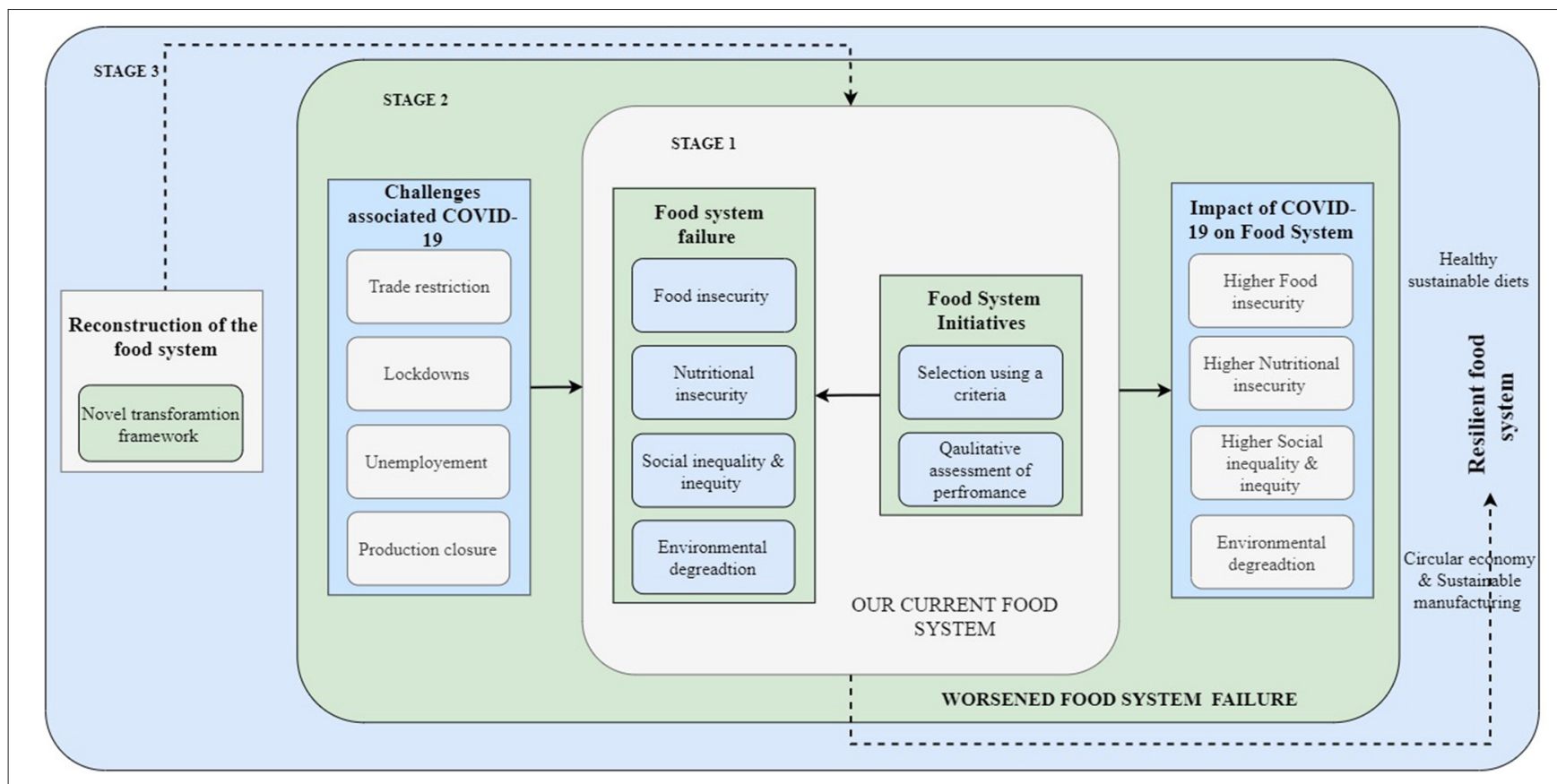

FIGURE 1 | Conceptual framework of the study.

TABLE 1 | Different narratives about the failure of the food system [extracted from Béné et al. (2019b)].

Food system failure

The inability of the system to feed the future world population

The inability of the system to deliver a healthy diet

The inability of the system to produce equal and equitable benefits

The depletion of the natural resources and environment upon which the food system depends
What is threatened and needs to be fixed?

Food availability

Nutrition security and health

Social justice, democratic process, small scale actors

Natural resource agrobiodiversity, energy-water-carbon efficiency demonstrated in the reports of the aforementioned authors. A detailed review and discussion of the different narratives regarding the failure of the food system are discussed extensively by Béné et al. (2019a). Table 1 presents a summary of the four narratives that describe the overarching problem of the failure of the food system.

The narratives presented in Table $\mathbf{1}$ can also be said to capture four dimensions of the food system challenges, namely, food production, malnutrition, social inequality and inequity, and environment impact. Closing the yield gap through sustainable and efficient agricultural production, nutritional gap, food decentralization, and reducing the footprint of the food system on the environment are the respective actions needed to address the gap that has created failures within our food system. These actions are necessary because for every dollar spent on food, society pays $\$ 2$ in health, environmental, and economic costs. It is important to note that the narratives provide strategic directions for transformations. Obviously, by explicitly providing nutritious and sustainable diet in light of these challenges, a critical part is formed in achieving resilient food system.

\section{Metrics for Evaluating Food System Initiatives}

To present a thorough evaluation of the performance of FSI in ameliorating food system failure, we adopt indices or indicators that characterize the different perspectives of food system failure. These indicators have been extracted from the following references (Feenstra et al., 2005; Pham and Smith, 2014; HLPE, 2017). Also, to ensure consistency and coherency with global sustainability metrics for food systems, the indicators presented in this study are similar to those commonly used to assess the progress made in the achievement of SDG 2 targets by the World Health Organization. Other indicators described in this section were selected from Béné et al. (2019a), who built a sustainability matrix by using a rigorous protocol. Incorporating these indicators will allow a thorough and consistent evaluation of FSI to create sustainable value. These indicators also serve as matrices to monitor what precisely needs to be fixed within the food system and whether food system initiatives are closing the gap to meet the 2030 agenda.

Turning now to the first narrative in which the challenge remains as to "how to close the yield gap," the global consensus within this domain is to sustainably intensify agricultural 
TABLE 2 | Indicators to measure support for food production.

\begin{tabular}{|c|c|c|c|}
\hline Performance indicator & Description & Objective & References \\
\hline Improved seed variety & $\begin{array}{l}\text { It reflects the support to provide hybrid } \\
\text { seeds that increase yield and are climate } \\
\text { resilient }\end{array}$ & $\begin{array}{l}\text { To provide farmers with hybrid } \\
\text { seed that improve crop yield }\end{array}$ & Hamukwala, 2012 \\
\hline Digital technology & $\begin{array}{l}\text { It reflects the support to advance digital } \\
\text { technology and innovations that improve } \\
\text { farming practices }\end{array}$ & $\begin{array}{l}\text { To provide and promote digital } \\
\text { technologies that accelerate } \\
\text { agriculture }\end{array}$ & $\begin{array}{l}\text { D'Odorico et al., 2018; } \\
\text { Kamilaris et al., } 2019\end{array}$ \\
\hline Application of fertilizer/pesticides & $\begin{array}{l}\text { It measures assistance in subsidizing the } \\
\text { cost of fertilizer }\end{array}$ & $\begin{array}{l}\text { To provide subsidized fertilizers } \\
\text { that increase yield }\end{array}$ & $\begin{array}{l}\text { Rasul and Thapa, } \\
\text { 2004; Dantsis et al., } \\
2010\end{array}$ \\
\hline Mechanization & $\begin{array}{l}\text { It measures the degree of support in } \\
\text { providing machinery in agriculture } \\
\text { production }\end{array}$ & $\begin{array}{l}\text { To provide machinery that } \\
\text { reduces the labor intensiveness } \\
\text { of agriculture }\end{array}$ & $\begin{array}{l}\text { Thompson and Blank, } \\
2000\end{array}$ \\
\hline Alternative practices such as agroecology & $\begin{array}{l}\text { It measures the advocacy for the adoption } \\
\text { of environmentally friendly agricultural } \\
\text { practices }\end{array}$ & $\begin{array}{l}\text { To support the adoption of } \\
\text { agroecology, circular economy } \\
\text { and regenerative agriculture }\end{array}$ & $\begin{array}{l}\text { Sherwood and Uphoff, } \\
\text { 2000; Hathaway, } 2016\end{array}$ \\
\hline Training (Communication and knowledge sharing) & $\begin{array}{l}\text { It measures the amount of training and } \\
\text { workshops to educate farmer groups and } \\
\text { another stakeholder on sustainable } \\
\text { production practices }\end{array}$ & $\begin{array}{l}\text { To communicate and share } \\
\text { knowledge on sustainable } \\
\text { agricultural protocols }\end{array}$ & $\begin{array}{l}\text { Van Cauwenbergh } \\
\text { et al., } 2007\end{array}$ \\
\hline
\end{tabular}

TABLE 3 | Indicators to measure the support to mitigate malnutrition.

\begin{tabular}{|c|c|c|c|}
\hline Performance indicator & Description & Strategic Objective & References \\
\hline Training and policy toward nutrient-rich food & $\begin{array}{l}\text { It expresses the level of education on } \\
\text { sustainable food consumption }\end{array}$ & $\begin{array}{l}\text { To promote sustainable food } \\
\text { consumption }\end{array}$ & Sanchez, 2020 \\
\hline Prevalence of stunted & $\begin{array}{l}\text { It reflects the percentage of stunting } \\
\text { among children aged } 0-5 \text { years }\end{array}$ & $\begin{array}{l}\text { To prevent malnutrition in all } \\
\text { forms (undernutrition, }\end{array}$ & $\begin{array}{l}\text { Abarca-Gómez et al., } \\
\text { 2017; Achicanoy et al., }\end{array}$ \\
\hline Prevalence of overweight and obesity & $\begin{array}{l}\text { It reflects the percentage of a defined } \\
\text { population with a body mass index (BMI) } \\
\text { of } 30 \mathrm{~kg} / \mathrm{m}^{2} \text { or higher }\end{array}$ & $\begin{array}{l}\text { overweight, micronutrient } \\
\text { deficiency, and stunted) }\end{array}$ & 2019 \\
\hline Wasting & $\begin{array}{l}\text { It reflects a recent and severe process of } \\
\text { substantial weight loss associated with } \\
\text { caloric deprivation (dietary energy } \\
\text { deficiency) or disease }\end{array}$ & & \\
\hline Non-communicable diseases & $\begin{array}{l}\text { It is the measure of the prevalence of } \\
\text { diet-related diseases such as cancer and } \\
\text { diabetes }\end{array}$ & $\begin{array}{l}\text { To reduce diet-related } \\
\text { communicable diseases such as } \\
\text { cancer, diabetes, coronary heart } \\
\text { disease }\end{array}$ & $\begin{array}{l}\text { Hugenschmidt, 2016; } \\
\text { Sabanayagam et al., } \\
2016 \text {; Achicanoy et al., } \\
2019\end{array}$ \\
\hline Diet diversification & $\begin{array}{l}\text { It expresses the low energy supply (in } \\
\mathrm{kcal} / \mathrm{caput} \text { per day) provided by cereals, } \\
\text { roots, and tubers as a percentage of the } \\
\text { total Dietary Energy Supply (DES) (in } \\
\text { kcal/caput per day) }\end{array}$ & $\begin{array}{l}\text { To ensure equal share of dietary } \\
\text { energy supply derived from } \\
\text { cereals, roots and tubers (\%) } \\
\text { (3-year average) }\end{array}$ & Elmadfa, 2005 \\
\hline
\end{tabular}

production; therefore, we consider factors that directly contribute to intensification, rather than expansion. Agricultural expansion, on the one hand, would require additional land use change, ecological habitat destruction, and $\mathrm{CO}_{2}$ emissions. A summary of the indicators is presented in Table 2. The second narrative focuses on how to alter the current production systems to meet the nutritional requirements both locally and globally. Once again, the challenge is "how to close the nutritional gap." Therefore, the key indicators selected for this narrative focus on how the current food system can provide nutritious and healthy food to feed the global population and limit foods that lead to obesity and diet-related diseases. A summary of the indicators is presented in Table 3. At this point, the authors would like to draw the attention of the readers to the fact that the indicators, wasting and stunting, are usually classified as underweight. Moving on, we consider the third narrative, which focuses on economic and social inequalities and inequities that the food system has generated. Table 4 presents a summary of the indicators used to describe this narrative. Finally, the fourth narrative, as discussed earlier, addresses the negative impact that the current food system has on the natural resources and environment. We selected indicators that measure the detrimental effect of the food system on the environment. Table 5 presents a summary of the selected indicators. 
TABLE 4 | Indicators to measure the support to mitigate economic and social inequality and inequity.

\begin{tabular}{|c|c|c|c|}
\hline Performance indicator & Description & Strategic objective & References \\
\hline $\begin{array}{l}\text { The concentration of food } \\
\text { distribution and marketing } \\
\text { activities }\end{array}$ & $\begin{array}{l}\text { It measures the level of quality, safety, and } \\
\text { sustainability in food distributions across a } \\
\text { demography }\end{array}$ & $\begin{array}{l}\text { To ensure equitable distribution } \\
\text { of food }\end{array}$ & Akkerman et al., 2010 \\
\hline Fair trade & $\begin{array}{l}\text { Fair trade is an alternative approach to } \\
\text { conventional trade based on a partnership } \\
\text { between producers and traders, } \\
\text { businesses, and consumers }\end{array}$ & $\begin{array}{l}\text { To promote inclusiveness in fair } \\
\text { trade networks }\end{array}$ & $\begin{array}{l}\text { Dubuisson-Quellier and } \\
\text { Lamine, } 2008\end{array}$ \\
\hline Food policy influence & $\begin{array}{l}\text { It is a call for people's right to shape and } \\
\text { craft food policy }\end{array}$ & $\begin{array}{l}\text { To advocate for a multisectoral } \\
\text { approach in shaping and crafting } \\
\text { food policies }\end{array}$ & $\begin{array}{l}\text { Windfuhr and Jonsén, } \\
\text { 2005; Patel, } 2009\end{array}$ \\
\hline $\begin{array}{l}\text { Labor force participation, } \\
\text { female (\% of female } \\
\text { population aged } 15+)\end{array}$ & $\begin{array}{l}\text { It is the proportion of the population aged } \\
15 \text { years or older that is economically } \\
\text { active: all people who supply labor for the } \\
\text { production of goods and services during a } \\
\text { specified period }\end{array}$ & $\begin{array}{l}\text { To promote equal labor force } \\
\text { participation }\end{array}$ & Achicanoy et al., 2019 \\
\hline $\begin{array}{l}\text { Employment in agriculture } \\
\text { (\% of total employment) }\end{array}$ & $\begin{array}{l}\text { It measures the stimulation of innovative } \\
\text { activities that create employment in } \\
\text { agriculture }\end{array}$ & $\begin{array}{l}\text { To support, expand, and invest } \\
\text { in business innovation within the } \\
\text { agricultural value chain, thereby } \\
\text { creating employment }\end{array}$ & $\begin{array}{l}\text { New Zealand, 2015; } \\
\text { Achicanoy et al., } 2019\end{array}$ \\
\hline $\begin{array}{l}\text { Gini index of land } \\
\text { distribution and tendency }\end{array}$ & $\begin{array}{l}\text { It measures the inequality in agricultural } \\
\text { land distribution measured, which ranges } \\
\text { from } 0 \text { (indicating perfect equity) to } 1 \text { (total } \\
\text { inequity) }\end{array}$ & $\begin{array}{l}\text { To ensure equal distribution of } \\
\text { agricultural land }\end{array}$ & $\begin{array}{l}\text { Achicanoy et al., 2019; } \\
\text { D'Odorico et al., } 2019\end{array}$ \\
\hline
\end{tabular}

TABLE 5 | Indicators to measure the support to mitigate the environmental damaged caused by the activities of the food system.

\begin{tabular}{|c|c|c|c|}
\hline Performance indicator & Description & Strategic objective & References \\
\hline Food loss & $\begin{array}{l}\text { A measure of postharvest and } \\
\text { preconsumer food loss as a ratio of the } \\
\text { total domestic supply of crops, livestock, } \\
\text { and fish commodities, in tons }\end{array}$ & To reduce food loss & $\begin{array}{l}\text { Lipinski et al., 2013; } \\
\text { Irani et al., } 2018\end{array}$ \\
\hline Renewable resource & $\begin{array}{l}\text { It refers to the adoption of alternative } \\
\text { sustainable energy resources to replace } \\
\text { the use of fossil energy in agricultural } \\
\text { production }\end{array}$ & $\begin{array}{l}\text { To improve the use of renewable } \\
\text { resources in agricultural } \\
\text { production }\end{array}$ & $\begin{array}{l}\text { Fluck, 2012; Liu et al., } \\
2017\end{array}$ \\
\hline Gas emission $\left(\mathrm{CO}_{2} \mathrm{eq}\right)$ in gigagrams & $\begin{array}{l}\text { It measures the emissions of greenhouse } \\
\text { gases (GHGs) by gas }\end{array}$ & $\begin{array}{l}\text { To mitigate/reduce GHG } \\
\text { emissions }\end{array}$ & Achicanoy et al., 2019 \\
\hline Resource consumption/agricultural land as \% of arable land & $\begin{array}{l}\text { It measures the total areas under } \\
\text { temporary crops, meadows and pastures } \\
\text { and lands temporary fallow }\end{array}$ & $\begin{array}{l}\text { To reduce superfluous resource } \\
\text { consumption }\end{array}$ & $\begin{array}{l}\text { Van Doorn and Bakker, } \\
2007\end{array}$ \\
\hline Irrigation/agricultural water withdrawal & $\begin{array}{l}\text { It measures the percentage of the total } \\
\text { freshwater withdrawn for agricultural } \\
\text { purposes }\end{array}$ & $\begin{array}{l}\text { To reduce the depletion of } \\
\text { freshwater resource for irrigation }\end{array}$ & Molden et al., 2010 \\
\hline
\end{tabular}

\section{Food System Transformation Initiatives Food System Initiatives Selection}

Given the continuous reappearance of food system challenges, there exist promising food system partnership to realize a healthy and circular food system transformation (Candel, 2018). The authors developed a threestep process to facilitate the selection of prominent transformational initiatives.

First, two keywords, "food system transformation" and "food system initiative," were used to search for expert reports and documentation and peer-reviewed articles from international organizations and agencies, Google Scholar, and the open web. It is important to note that previous studies by Davidson et al. (2019) and BCFN, MUFFP (2018) considered single initiatives, which does not provide a holistic overview in assessing the efforts of global initiatives. Therefore, this study is the first of its kind in considering a sampled size of 17 global food system initiatives. Additionally, the regions of operations of the initiatives were captured. In the second step, we evaluate the regions in the world in which the sampled initiatives operate or have conducted projects. As at 2018, almost 260 million people in Africa (90\% living in 
Sub Saharan Africa), more than 500 million people in Asia, and 42.5 million in Latin America and the Caribbean were undernourished and continue to experience other prevalent food system challenges (FAO, 2019). This motivated the screenings of food system initiatives per their operations within the aforementioned regions. Next, a strict inclusion/exclusion protocol of operating in at least two of the demographic regions was employed. After carefully subjecting the selected FSI to the inclusion/exclusion protocol, 10 were selected. In the final step, we filter the FSI from the second step per the availability of appropriate documentation of activities between 2010 and 2019. This step proved crucial as it contributes to the reproducibility of the study. The stepwise results of the methodology discussed above are presented in Table 6.

\section{RESULTS AND DISCUSSION}

\section{Brief Profile of the Selected Food System Initiatives}

This section presents an overview of the selected FSI by considering multiple attributes including core objectives; key interventions; key public, private, and science partners involved; core funders of the initiative; documented or delivered impact; regional focus; and association with different food system initiatives.

\section{One Planet Sustainable Food Systems Programme}

The One Planet Sustainable Food Systems Programme was launched in October 2015 as one of the sectoral programs of action by the One Planet network with a core objective of "catalyzing more sustainable food consumption and production patterns through multistakeholder action." It was formed to implement the commitments of the 10-Year Framework of Programmes on Sustainable Consumption and Production Patterns (10YFP), which was adopted at the United Nations Conference on Sustainable Development (Rio+20) in 2012 (Bortoletti and Lomax, 2019). The key actors and partners within the program include Switzerland, Costa Rica, and World Wildlife Fund, in collaboration with Multistakeholder Advisory Committee that consists of 20 members from five different stakeholder clusters, namely, (1) Government agencies such as US Department of Agriculture; (2) Civil society organizations such as IFOAM-Organic International; (3) Research and technical institutions; (4) UN agencies and other international organizations, such as the FAO; and (5) private sector such as Nestle and Food Networks (Hatt et al., 2016). The initiative is involved in numerous projects, with the most notable one being the Pesticide Risk Tool, which has been used by the Red Tomato Eco Apple program. The program has recorded a 50\% reduction in the average number of high risks per pesticide application since 2004 and a corresponding 35\% pesticide reduction since 2010. More recently, the tool has been adopted by major food retailers to monitor, analyze, and identify major risk-related areas in their supply chain to ensure pesticide risk reduction (Solon et al., 2018).

\section{Food Action Alliance}

The FAA was launched in 2019 at the third world economic forum with the support of the International Fund for Agricultural Development, Rabobank and the World Economic Forum in partnership with the Alliance for a Green Revolution in Africa, the African Development Bank, the International Center for Tropical Agriculture, the World Business Council on Sustainable Development, and many others from business, civil society, and international organizations (World Economic Forum, 2019). The initiative aims to nurture the next generation of value chain partnerships for large-scale food system transformation, bringing together a coalition of partners from all sectors-government, business, civil society, international organizations, and farmers' associations. The FAA is strategically positioned to serve as a platform that will deliver in-country action, supporting a vision of sustainable food systems that deliver better, faster, and at scale on food security and nutrition, inclusive growth and decent jobs, and environmental sustainability and climate resilience-in line with the UN SDGs 2030 Agenda (World Economic Forum, 2020). The initiative is involved in flagship programs in Latin America, India, Southeast Asia, and Africa (initial programs in Ghana and Togo).

\section{The Milan Urban Food Policy Pact}

Taking into account the challenges such as resource scarcity that threatens the food system, the Milan Urban Food Policy Pact was initiated to "coordinate international food policies and engage major cities to identify their contributions toward making positive changes." The policy pact was promoted by the Mayor of Milan in September 2014 and signed in October 2015 by 140 cities. It currently holds the signatories of more than 210 cities across the globe. The core objective of the pact is "to increase the overall sustainability of the food system and consistently drive it toward a circular economy by diminishing food losses and food waste." Some of the recommended actions of the policy pact include (1) reducing surplus and food waste, through education of citizens on healthy eating and food waste management and (2) promoting the recovery of surplus food by devising redistribution channels for sharing it with other operators in the value chain. Additionally, the pact addresses food system sustainability dimensions, such as (1) governance, (2) sustainable diets and nutrition, (3) social and economic equity, (4) food production, (5) food supply and distribution, and (6) food waste. So far, Copenhagen's Food Council has led the way by mandating that $90 \%$ of the food served in their canteens must be organic. The initiative works in collaboration with experts, institutions, and foundations such as the FAO, C40 Cities, Ruaf Foundation, Ellen Macarthur Foundation, and the Cuny Urban Food Policy (BCFN, MUFFP, 2018; Candel, 2019).

\section{Global Alliance for the Future of Food}

It was formed in 2012 by a strategic alliance of philanthropic donors with a core objective "to accelerate the transition toward agroecology as the core solution to the future of food system." The core founders of the initiative include David Rockefeller Foundation, McKnight Foundation, and many 
TABLE 6 | The three-step methodology for selecting FSI.

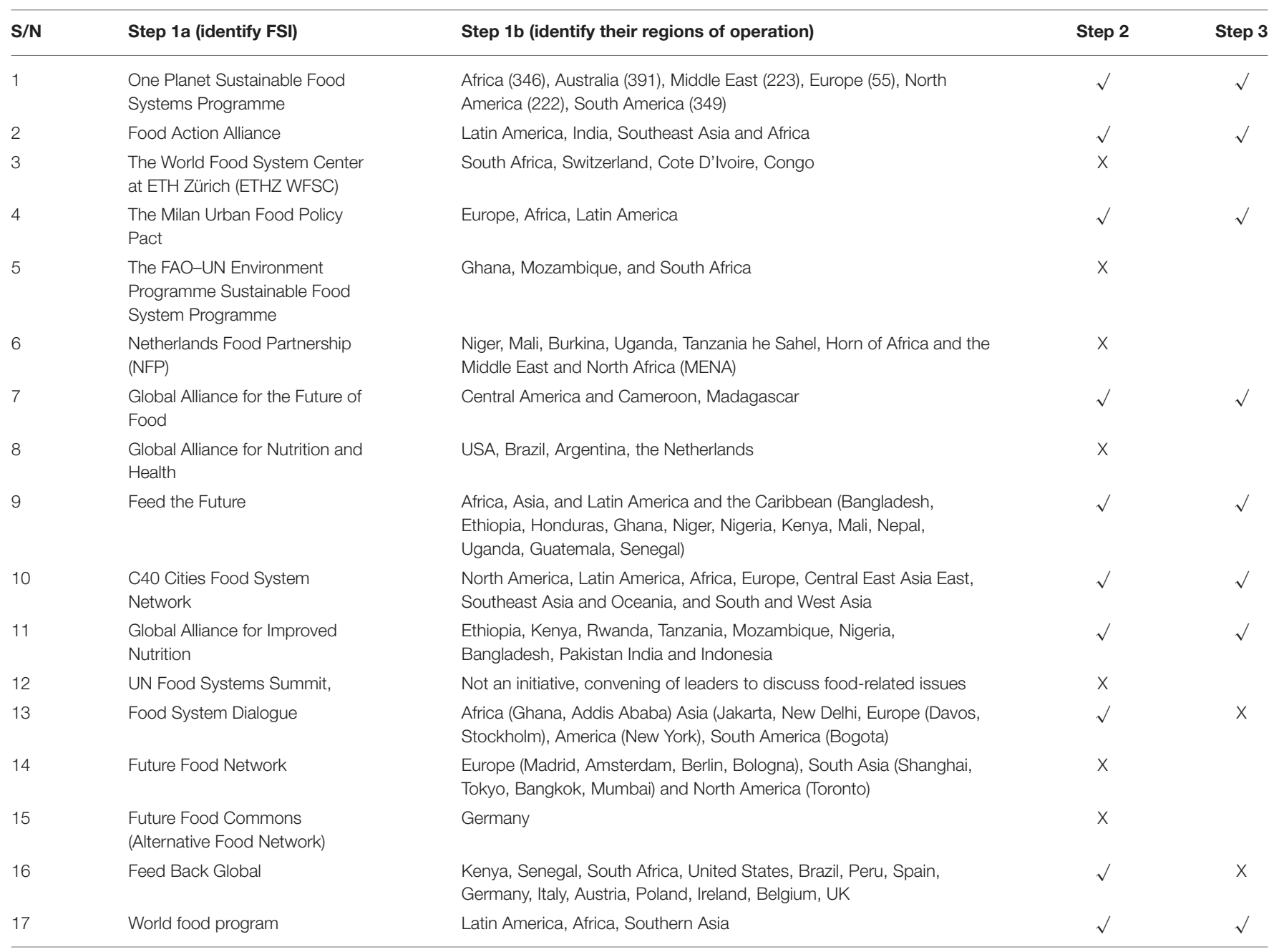

$\sqrt{ }$, Meets requirements; $X$, Does not Meets requirements.

others. The activities of the initiative are focused on three impact areas, agroecology, health and well-being, and true cost accounting. Members of the initiative are engaged in a range of supportive actions such as system approach for the transition of a biodiversified agroecosystem, which is currently studying different sites such as the production of rice in Madagascar and Agroforestry system in Central America and Cameroon. Other key intervention also addresses the vulnerabilities experienced by a small and marginalized farmer in India. Through its strong collaboration with the Biovision Foundation for ecological development, it has initiated the beacon of hope, which was launched in 2019. The initiative is supporting global initiatives such the Valley Organic, North East Slow Eat Food and Agrobiodiversity, the Milan Food Pact, and World Food Center ETH Zurich "to accelerate the transformation of sustainable food systems."

\section{Feed the Future}

Feed the Future emerged in 2010, after one of the most devastating food shortages across the globe in 2007 and 2008, to "equip partner countries and communities with the skills and knowledge to feed themselves," hence alleviating poverty and hunger. The initiative is in partnership with the US Government and agencies such as USAID, universities, businesses, and nonprofit organizations (Briggs, 2016). Throughout the years, the initiative has supported a multitude of global shocks including the Ebola outbreak in West Africa and armyworm invasion in Africa. For example, in Ghana, it has achieved a $12 \%$ reduction in poverty between 2012 and 2015 and 17\% reduction in stunting among children younger than 5 years within the same time frame. So far, in all its regions of operation, 23.4 million people live above poverty, 3.4 million more children live free from stunting, and 5.2 million more families live free from hunger. Currently, the initiative has activities going in Africa (Ethiopia, Ghana, Niger, Nigeria, Kenya, Mali, Uganda, and Senegal), Asia (Bangladesh and Nepal), and Latin America and the Caribbean (Honduras and Guatemala) (America and Fund, 2016).

\section{Global Alliance for Improved Nutrition}

One in every three people worldwide is malnourished; therefore, the Global Alliance for Improved Nutrition (GAIN), a Swissbased organization, was established in 2002 with the core 
objective to "galvanize efforts by the public and private sectors to end malnutrition." Aside from reaching out to more than 600 million people with nutritious food as of the first decade of its establishment, the organization has expanded with new programs to include maternal, infant, and young child nutritional improvement agendas. Through its numerous partnerships with government, philanthropic organizations, business and civil societies, and international organization, GAIN has experienced positive results. Through its fortification of maize meal and wheat flour with folic acid, the organization has reduced Neural tube defect in South Africa by 30\%. Similarly, through its fortification of soy with iron in China, anemia levels have dropped drastically by more than $30 \%$. Currently, the key focus of the organization is to tackle issues of malnutrition in countries such Ethiopia, Kenya, Rwanda, Tanzania, Mozambique, Nigeria, Bangladesh, Pakistan, India, and Indonesia, where it is very prevalent. The program is in partnership with different food system initiatives such as the Amsterdam Initiative Against Malnutrition, business platform for nutrition research, commercialization of biofortified crops, Global Fortification Data Exchange, and the SUN Business Network (Moench-Pfanner and Van Ameringen, 2012; Geissler and Powers, 2017).

\section{C40 Food System Network}

The Food System Network was set up by the mayor of London, Ken Livingston, in 2005 with an initial membership of 18 cities. The network was formed to address "bureaucratic and political obstacles to the effective delivery in urban-focused climate initiatives" (Acuto, 2013). Through this core objective, C40 aims to help the world's big city practitioners to improve and accelerate climate actions. The network boasts of more than 94 affiliated city partners and members from the largest cities in Africa, Asia and Oceania, North and Latin America, and Europe, covering close to 650 million people (Bortoletti and Lomax, 2019; Watts et al., 2019). The network works in strong partnership with united cities and local government, World Resource Institute, the World Bank, and Clinton Foundation. Core funders of the initiative include Johnson \& Johnson, the UK Government, Clean Air Fund, and Citi Foundation. A broad overview of the past decade of activities and agendas by the C40 Food System Network is reported extensively by Davidson et al. (2019).

\section{World Food Programme}

The World Food Programme (WFP) is an international program set in 1963, with the objective of "delivering food assistance in emergencies and working with communities to improve nutrition and build resilience." Governments, corporate bodies, and individuals are the core funders of this initiative. The WFP works in collaboration with other United Nations organization agencies (such as the World Health Organization), over 1,000 Non-governmental agencies (such as World Relief and Islamic Vision), global food system initiatives (such as GAIN and Scale-Up Nutrition), private sectors (such as the Mastercard Foundation), and researchers (such as the International Food Policy Research Institute). Remarkably, in 2019, the WFP aided more than 97 million people in 88 countries in Africa, Latin America, and Asia with food relief programs. Similarly, the initiative's school meal and nutritional programs reached 17.3 million and 17.2 million beneficiaries, respectively.

In summary, Table 7 presents an overview of the different food system initiatives discussed. The summary and overview shown in Table 7 suggest that although some of these initiatives address only a subset of the dimensions and elements of the food system, they all contribute toward more sustainable food systems.

\section{Analysis of the Global Food System Initiative Through the Lens of Food System Failure}

Table 8 presents a qualitative assessment of initiatives in their support for tackling food system failure. The highlighted green sections indicate an initiative that has undergone projects that measure the corresponding indicators. The orange sections indicate initiatives that have the indicators mentioned in their policy document; however, the authors could not identify any explicit report or information from online resources demonstrating that it had carried out a project in light of their documented policies. On the other hand, the gray sections demonstrate initiatives that do not support or have any published report relating to the highlighted indicators of food system failure. At this point, the authors would like the readers to note that the assessment presented was based on research papers and published reports on completed and ongoing projects, as well information displayed on the respective initiative websites. For example, an extensive study on the different strategies by signatories policy instruments for deploying these strategies and their current impact under the Milan urban food policy pact has been discussed by Candel (2019).

From Table 8, five interesting observations can be made: (1) all selected FSIs discussed above tend to address the challenge of malnutrition, which implies that it is of great interest across the globe; (2) issues regarding the environmental impact of food systems are widely tackled; (3) there exist similarities in terms of goals across the initiatives (this is probably due to how they all tend to address food-insecurity challenges); (4) food production and food security insecurity and inequality are scarcely discussed [a possible reason for this observation is the spillover effect, which is widely held by FSIs when defining objectives; this idea refers to a situation where FSIs set a single objective with the assumption that while achieving it, other objectives will be met because of their independencies; in reality, this is often not the case, hence the observed patterns in the Table 8]; (5) While the initiatives are doing immense work in some areas, it is very clear that the focus has not been on closing the yield. This is because the initiatives are working in countries where there is small-scale farming; hence, the focus has been on empowering and alleviating poverty. To achieve agricultural intensification, new initiatives working with other government will need to be established, or perhaps existing initiatives can restructure their implementation strategies. In summary, a considerable progress is being made in championing SDG 2.

In summary, we have reviewed eight major FSIs and provided a summary of their key interventions, as well as a high-level analysis of their efforts, to critically transform our food system in 
TABLE 7 | Summary of the different initiatives in relation to sustainable food system.

\begin{tabular}{|c|c|c|c|c|c|c|}
\hline S/N & Initiative & $\begin{array}{l}\text { Main sustainability } \\
\text { dimension(s) addressed }\end{array}$ & $\begin{array}{l}\text { Main food system } \\
\text { element addressed }\end{array}$ & $\begin{array}{l}\text { Key interventions or food } \\
\text { system outcomes }\end{array}$ & $\begin{array}{l}\text { Shortcomings due to } \\
\text { COVID-19 disruptions }\end{array}$ & $\begin{array}{l}\text { Affiliated donor } \\
\text { landscape }\end{array}$ \\
\hline 1 & $\begin{array}{l}\text { One Planet Sustainable } \\
\text { Food Systems Programme }\end{array}$ & $\begin{array}{l}\text { Environment and food } \\
\text { nutrition and security }\end{array}$ & $\begin{array}{l}\text { Production and } \\
\text { consumption, food loss and } \\
\text { waste }\end{array}$ & $\begin{array}{l}\text { A shift toward sustainable } \\
\text { consumption and } \\
\text { production }\end{array}$ & $\begin{array}{l}\text { Concerns for food } \\
\text { system actors and the } \\
\text { difficulties that has led to } \\
\text { gaps in food production, } \\
\text { access, and availability } \\
\text { Role of diet in } \\
\text { heightening the health } \\
\text { impact of COVID-19 }\end{array}$ & $\begin{array}{l}\text { International Fund for } \\
\text { Agriculture Development } \\
\text { (IFAD) } \\
\text { Global Nature Fund }\end{array}$ \\
\hline 2 & $\begin{array}{l}\text { Global Alliance for the } \\
\text { Future of Food }\end{array}$ & All dimensions & All elements & $\begin{array}{l}\text { The transition toward } \\
\text { agroecology for sustainable } \\
\text { food system }\end{array}$ & $\begin{array}{l}\text { Mobilization of diver } \\
\text { agents of change to } \\
\text { better comprehend the } \\
\text { current system, develop } \\
\text { solutions and } \\
\text { communicate actions to } \\
\text { community } \\
\text { Structural inequality at } \\
\text { the heart of the } \\
\text { food system }\end{array}$ & $\begin{array}{l}\text { Christensen Fund } \\
\text { Clerence E. Heller } \\
\text { Foundation } \\
\text { David Rockefeller fund } \\
\text { Cariplo Fondazione } \\
\text { McKnight Foundation } \\
\text { Swift Foundation }\end{array}$ \\
\hline 3 & World Food Programme & $\begin{array}{l}\text { Food nutrition and social } \\
\text { equality and inequality }\end{array}$ & Food consumption & $\begin{array}{l}\text { To provide emergency food } \\
\text { relief and improve nutrition }\end{array}$ & $\begin{array}{l}\text { Resourcing situation (funds } \\
\text { to continue to scale up } \\
\text { COVID response) }\end{array}$ & $\begin{array}{l}\text { Government, } \\
\text { Non-Governmental agency, } \\
\text { Private individuals }\end{array}$ \\
\hline 4 & Food Action Alliance & Nutrition security & Food value chain & $\begin{array}{l}\text { To strengthen the agriculture } \\
\text { value chain to produce food } \\
\text { efficiently and sustainable }\end{array}$ & $\begin{array}{l}\text { Food insecurity spreading to } \\
\text { everyone's plate }\end{array}$ & $\begin{array}{l}\text { International Fund for } \\
\text { Agriculture Development } \\
\text { (IFAD) } \\
\text { Rabobank } \\
\text { African Development Bank }\end{array}$ \\
\hline 5 & $\begin{array}{l}\text { C40 Cities Food System } \\
\text { Network }\end{array}$ & Environment & Food and climate & $\begin{array}{l}\text { To introduce consumption } \\
\text { interventions to reduce } \\
\text { food-related emissions }\end{array}$ & $\begin{array}{l}\text { Food access to vulnerable } \\
\text { population }\end{array}$ & $\begin{array}{l}\text { Bloomberg philanthropies } \\
\text { Children Investment Fund } \\
\text { Foundation } \\
\text { Clean Air Fund } \\
\text { Citi Foundation }\end{array}$ \\
\hline 6 & Milan Food Systems Pact, & $\begin{array}{l}\text { Social, economic, food } \\
\text { safety and security, nutrition }\end{array}$ & $\begin{array}{l}\text { Food waste, training and } \\
\text { knowledge, food distribution }\end{array}$ & $\begin{array}{l}\text { A drive toward a circular } \\
\text { economy to reduce food } \\
\text { waste and loss }\end{array}$ & $\begin{array}{l}\text { Food access to the } \\
\text { vulnerable groups }\end{array}$ & $\begin{array}{l}\text { Ellen Macarthur Foundation } \\
\text { Rauf Foundation }\end{array}$ \\
\hline 7 & $\begin{array}{l}\text { Global Alliance for Improved } \\
\text { Nutrition }\end{array}$ & Nutritional security & Consumption & $\begin{array}{l}\text { To improve the consumption } \\
\text { of nutritious food and safe } \\
\text { food especially by the most } \\
\text { vulnerable }\end{array}$ & $\begin{array}{l}\text { Protecting the nutritional } \\
\text { status of the population } \\
\text { most threatened by } \\
\text { COVID-19 }\end{array}$ & $\begin{array}{l}\text { Bill and Melinda Gate } \\
\text { Foundation } \\
\text { The Rockefeller Foundation } \\
\text { The Waterloo Foundation } \\
\text { Good ventures } \\
\text { Children's Investment } \\
\text { Fund Foundation }\end{array}$ \\
\hline 8 & Feed the Future & Food security & $\begin{array}{l}\text { Production, marketing, } \\
\text { consumption }\end{array}$ & $\begin{array}{l}\text { To equip people with the } \\
\text { tools to feed themselves }\end{array}$ & $\begin{array}{l}\text { Prevent widespread hunger, } \\
\text { malnutrition, and poverty }\end{array}$ & US Government \\
\hline
\end{tabular}


initiative

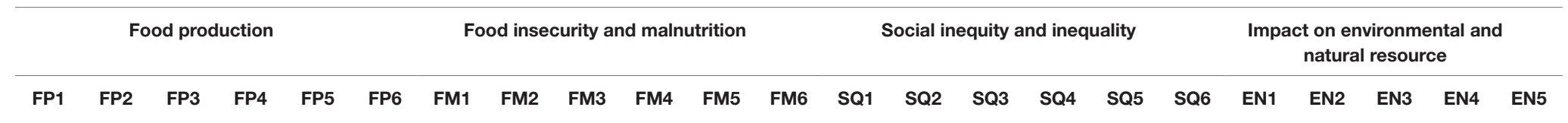

One planet

sustainable food

systems

programme

Global alliance for

the future of food

World food

programme

Food action

alliance

C40 cities food

system network

Milan urban food

policy pact

Global alliance for

improved nutrition

Feed the future

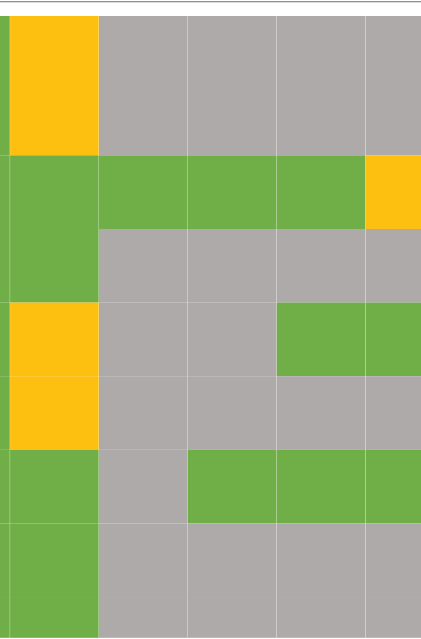

Initiative is working

FP1, Chemical fertilizer: FP2, Agroecology: FP3, Improved seed: FP4, Digital technology: FP5, Mechanization; FP6, Training.

FM1, Education and train; FM2, Stunting; FM3, Overweight/obesity; FM4, Wasting; FM5, Non-communicable disease; FM6, Diet diversification.

SQ1, Gini index; SQ2, Fair trade; SQ3, Food distribution; SQ4, Employment; SQ5, Labor participation; SQ6, Food sovereignty.

EN1, Gas emission; EN2, Natural resource; EN3, Resource consumption; EN4, Food loss and waste; EN5, Agricultural water.

Initiative is working (green); the initiative does not support this driver (grey); No explicit information although stated core objectives (orange). 


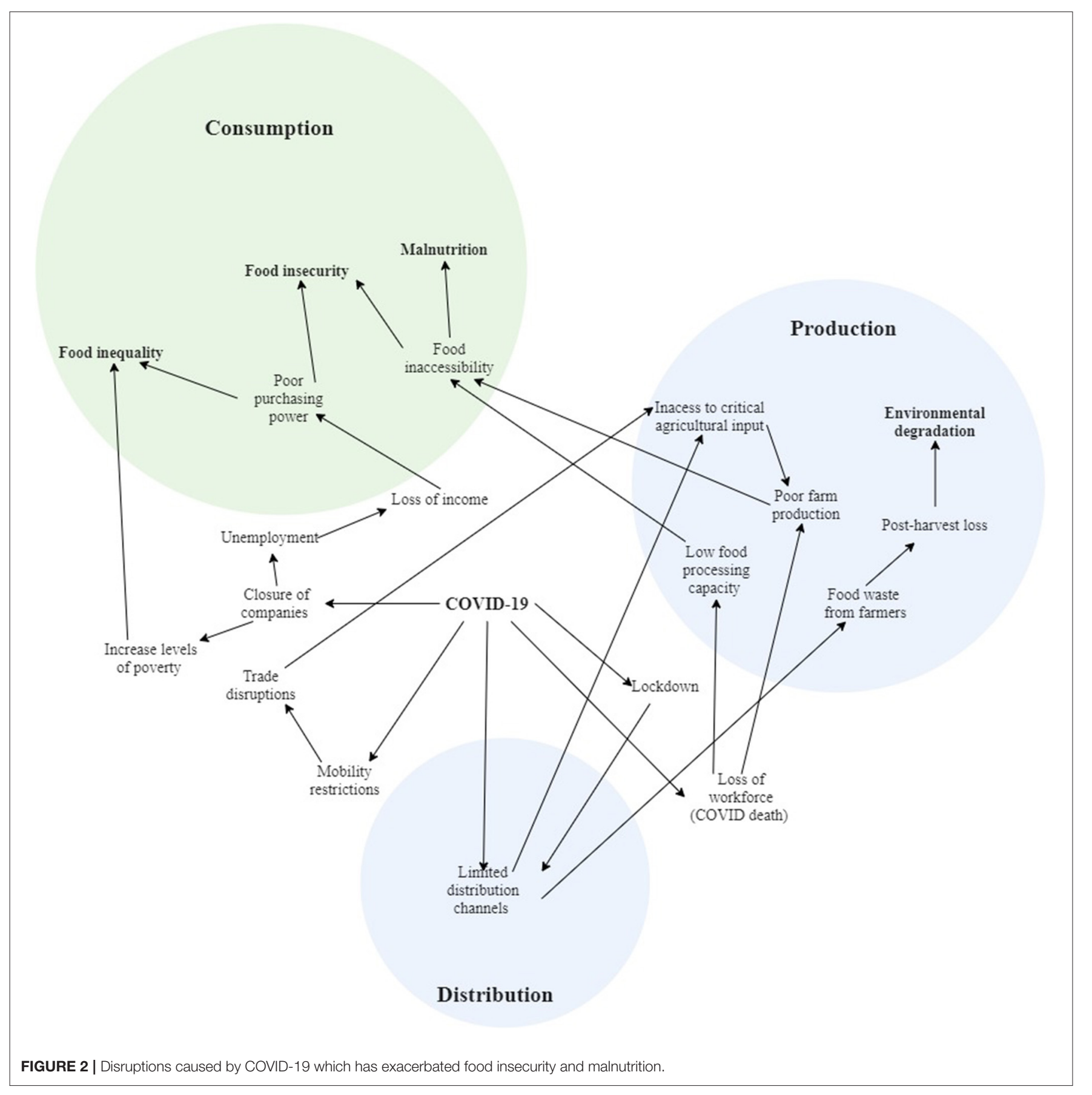

the face of a rapidly changing world. In the section that follows, we discuss an account on the influential theories on building food system resilience in the context of a pandemic from literature and present a framework that can serve as navigation to global FSI in achieving their objective.

In the wake of the COVID-19 pandemic, access to healthy and nutritious food has never been more critical. Between 2016 and 2019, this number of people experiencing food insecurity increased at a lower rate, that is, from 108 to 135 million, which is fewer than 30 million people. This was attributed to climate change, conflict, and economic downturn. Although the World Food Program had predicted the number to rise to 140 million people, COVID-19 exacerbated food security crisis to 265 million people at the end of 2020 (Husain and Agamile, 2020). Vulnerable groups such as women, smallholder farmers, and the urban poor will be the hardest-hit. Therefore, the subsequent subsections are pivotal in navigating global FSI to build a resilient food system in the era of the COVID-19 crisis. The following section presents tipping points within the food system as a result of the impact of the COVID-19 pandemic, in which specific 
TABLE 9 | Innovative strategies to integrate into the current food system.

\begin{tabular}{|c|c|c|}
\hline Strategic component & Opportunities & References \\
\hline Innovative technology and mechanization & $\begin{array}{l}\text { - Breakthrough technology for harvesting crops } \\
\text { - Technologies and facilities for storing food }\end{array}$ & $\begin{array}{l}\text { Altieri and Nicholls, 2020; Fadele } \\
\text { et al., 2020; Savary et al., } 2020\end{array}$ \\
\hline Advanced transport and distribution channels & $\begin{array}{l}\text { - Opportunities also arise in using delivery services to } \\
\text { transport directly from the farm to consumer homes (short } \\
\text { food supply chain) } \\
\text { - Technologies capable of delivering foods to consumers } \\
\text { without human intervention }\end{array}$ & Hobbs, 2020; Singh et al., 2020 \\
\hline Improved education & $\begin{array}{l}\text { - Education on the intake of a balanced diet and food } \\
\text { supplements through social media for urban areas and } \\
\text { communities' groups for areas with limited access to the } \\
\text { internet } \\
\text { - Building capacity of farmers through smallholder farmer } \\
\text { groups to adopt the technologies and transition to new } \\
\text { distribution channels }\end{array}$ & $\begin{array}{l}\text { Belanger et al., 2020; Yancy, } \\
2020\end{array}$ \\
\hline Financing & $\begin{array}{l}\text { - Financial support will be required for manufacturing and } \\
\text { acquisition of technologies and delivery systems, research, } \\
\text { education } \\
\text { - Support will also be required to expand the innovative } \\
\text { distribution channels as well as scale up the technologies }\end{array}$ & $\begin{array}{l}\text { Amjath-Babu et al., 2020; } \\
\text { Ragasa and Lambrecht, } 2020\end{array}$ \\
\hline Revised policies & $\begin{array}{l}\text { - Opportunity to reorient policies that influence food system } \\
\text { performance as well as build better resilience to pandemics } \\
\text { such as COVID-19 }\end{array}$ & $\begin{array}{l}\text { Galanakis, 2020; Klassen and } \\
\text { Murphy, 2020; Ragasa and } \\
\text { Lambrecht, } 2020\end{array}$ \\
\hline
\end{tabular}

changes can be implemented by FSIs to achieve specific changes that improve the resilience of the food system.

\section{How COVID-19 Has Disrupted Our Food System}

At the beginning of the twenty-first century, there came SARS (severe acute respiratory syndrome), which emerged in China, and then bovine spongiform encephalopathy, which peaked in the United Kingdom; later, the H1N1 influenza pandemic struck certain parts of Asia, from the Middle East respiratory syndrome (also known as MERS) to Ebola, which affected some parts of West and Central Africa, without the rest of the world experiencing any detrimental effect. Now, the novel coronavirus (COVID-19) has impacted the 7.8 billion people on the planet from a multifaceted angle. It has revealed weaknesses that exist not only within our food system, but also the health system, and has raised alerts on personal hygiene activities, which up to now were neglected. The one question that arises is: "How did COVID-19 have an enormous impact on our food system?" Perhaps it is because the food supply chain is one of the most complicated systems with diverse actors and complex interactions with other systems, hence the most vulnerable/susceptible to disruptions.

In response to the COVID-19 pandemic, measures such as social distancing, mobility restrictions, and closure of public and some workplaces were imposed by governments to contain the spread of the virus. However, these measures, as per the reports of the FAO (June 2020), have increased the levels of acute food insecurity and malnutrition in some parts of the world. This has stimulated various discourses within the stakeholders of the food value chain on how to intensify the provision of nutritious, healthy, and safe food to the world population.
Figure 2 illustrates a causal link that maps out the impacts of COVID-19 in increasing food insecurity, malnutrition, food inequality, and environmental degradation. It is apparent from the figure that low processing capacities due to shutdowns, as well as transportation restrictions, resulted in farmers discarding their produce (Kumar et al., 2020; Laborde et al., 2020). Also, loss of workforce due to COVID death and a lack of access to vital agricultural inputs due to trade disruptions have resulted in low agricultural production (Zhang et al., 2020). Pu and Zhong (2020) studied how the government's efforts to mitigate the spread of the virus not only hinders the availability of agricultural inputs, such as fertilizers and machinery, but also blocks production flows/channels, ultimately underpinning the production capacity of countries.

Moreover, the loss of income, which exacerbated the poor purchasing power of people, was mainly due to layoff and shutting-down of some companies. This has further increased the poverty and hunger levels in some parts of the world and crippled household and the more vulnerable populations' resilience to food insecurity and malnutrition (Gralak et al., 2020; Laborde et al., 2020; Stephens et al., 2020). In summary, the disruptions have limited food accessibility in areas already affected by food insecurity (Valdramidis et al., 2020). Power et al. (2020), reported on how COVID-19 has also exposed food inequality, reaffirming how fragile our food system is. Likewise, Ragasa and Lambrecht (2020) investigated the effect of the pandemic and proposed opportunities for gender equality in the current food system. Recent work by Béné (2020) has established the disruptions caused by the pandemic on the different actors on the food value, juxtaposing the effects of the direct and indirect impact on food insecurity. The impacts mentioned previously were mainly caused by the lockdown and mobility restrictions 
TABLE 10 | Redesign of the contributions of key actors in building a resilient food system against COVID-19.

\begin{tabular}{|c|c|c|}
\hline Actors & Contributions & References \\
\hline Research and thought community & $\begin{array}{l}\text { - Engage in a coordinate effort with other stakeholders to } \\
\text { investigate and introduce diverse market channels to } \\
\text { distribute food } \\
\text { - Conduct research that focuses on the health and nutrition } \\
\text { implications of the pandemic }\end{array}$ & Pérez-Escamilla et al., 2020 \\
\hline Government (policymakers) & $\begin{array}{l}\text { - Reevaluate/reorient and strengthen policies regarding food } \\
\text { prices to avoid price hikes } \\
\text { - Restructure existing trade policies to allow safe passage of } \\
\text { food commodities and agricultural inputs across the border } \\
\text { - A collaborative effort with all stakeholders to expand } \\
\text { food banks }\end{array}$ & $\begin{array}{l}\text { Laborde et al., 2020; Reardon } \\
\text { et al., } 2020\end{array}$ \\
\hline Civil society groups & $\begin{array}{l}\text { - Intensify the organization of food charity programs at the } \\
\text { national and community levels in very deprived } \\
\text { communities to meet the less privileged } \\
\text { - Advocate for the adoption of a short and intertwined food } \\
\text { supply chain } \\
\text { - Improve and amplify education about a balanced diet and } \\
\text { the inclusion of food commodities or ingredients that } \\
\text { provide the necessary nutrients that enhance the immune } \\
\text { system } \\
\text { - Advocate for hygienic practices }\end{array}$ & $\begin{array}{l}\text { Ivanov and Dolgui, 2020; Rowan } \\
\text { and Galanakis, } 2020\end{array}$ \\
\hline Private sectors/donor landscape & $\begin{array}{l}\text { - Intensify the adoption of remote working strategies and } \\
\text { implement strict safety protocols } \\
\text { - Identify essential ingredients that will be in short supply } \\
\text { during pandemics and store them or develop alternate } \\
\text { ingredients for the manufacturing of their products/ } \\
\text { modified recipes } \\
\text { - Increase funds to expand food banks and support charity } \\
\text { food programs } \\
\text { - Provide financial support for scientific research }\end{array}$ & $\begin{array}{l}\text { McKee and Stuckler, 2020; } \\
\text { Pérez-Escamilla et al., } 2020\end{array}$ \\
\hline Development partners (technology manufacturers) & $\begin{array}{l}\text { - Accelerate efforts for the development of innovative } \\
\text { technologies that reduce the overdependence on labor for } \\
\text { agricultural production } \\
\text { - Support the transition toward Industry } 4.0 \text { in food } \\
\text { processing companies } \\
\text { - Increase support and investment into storage facilities on } \\
\text { farms to avoid food waste }\end{array}$ & Hobbs, 2020 \\
\hline
\end{tabular}

imposed by governments and local authorities. The effects of these disruptions and current trend strongly indicate we will not meet the SDGs 2 by 2030.

Again, in middle- and low-income countries, the COVID19 pandemic forced consumers to purchase staple and nonperishable foods, leading to waste of perishable foods in markets. Also, the mobility restrictions resulted in reduced number of people in markets, consequently leading to an increased postharvest loss. In situations such as these, all resources (land, energy, labor, and capital) used to produce the food are wasted (Galanakis, 2020).

In summary, as illustrated in both Figures 1, 2, COVID-19 has heightened many fragilities in our food system, increasing food insecurity and malnutrition and social inequality and inequity. In the long run, COVID-19, economic recessions, climate change (heavy rains), deterioration of soil quality, stresses (pest invasions such as locust infections and the emergence of pathogens), and increased subjection of arable land for industrial, residential, and animal feed have put our food system to test.

\section{Reflective Reconstruction From the Lessons Learned}

To tackle the challenges introduced by COVID-19 pandemic on the current food system, several researchers (Harris et al., 2020; Stephens et al., 2020) have reported numerous intervention strategies, whereas other authors (Ahmed et al., 2020; Farrell et al., 2020) have convincingly shown pathways for a potential policy response to build resilience toward the pandemic. Drawing on an extensive range of sources on the realigning our food system during the pandemic, the authors set out to synthesize these studies, identify overarching recommendations, and develop an innovative transformation model that guarantees we build back better.

Although the World Health Organization declared that the COVID-19 pandemic will persist for the next 5 years, there still exists a high degree of uncertainty on the pandemic time duration. Therefore, there will be a need for a systematic transformation framework that can be adopted immediately by FSI to achieve healthy sustainable diets and circular and 


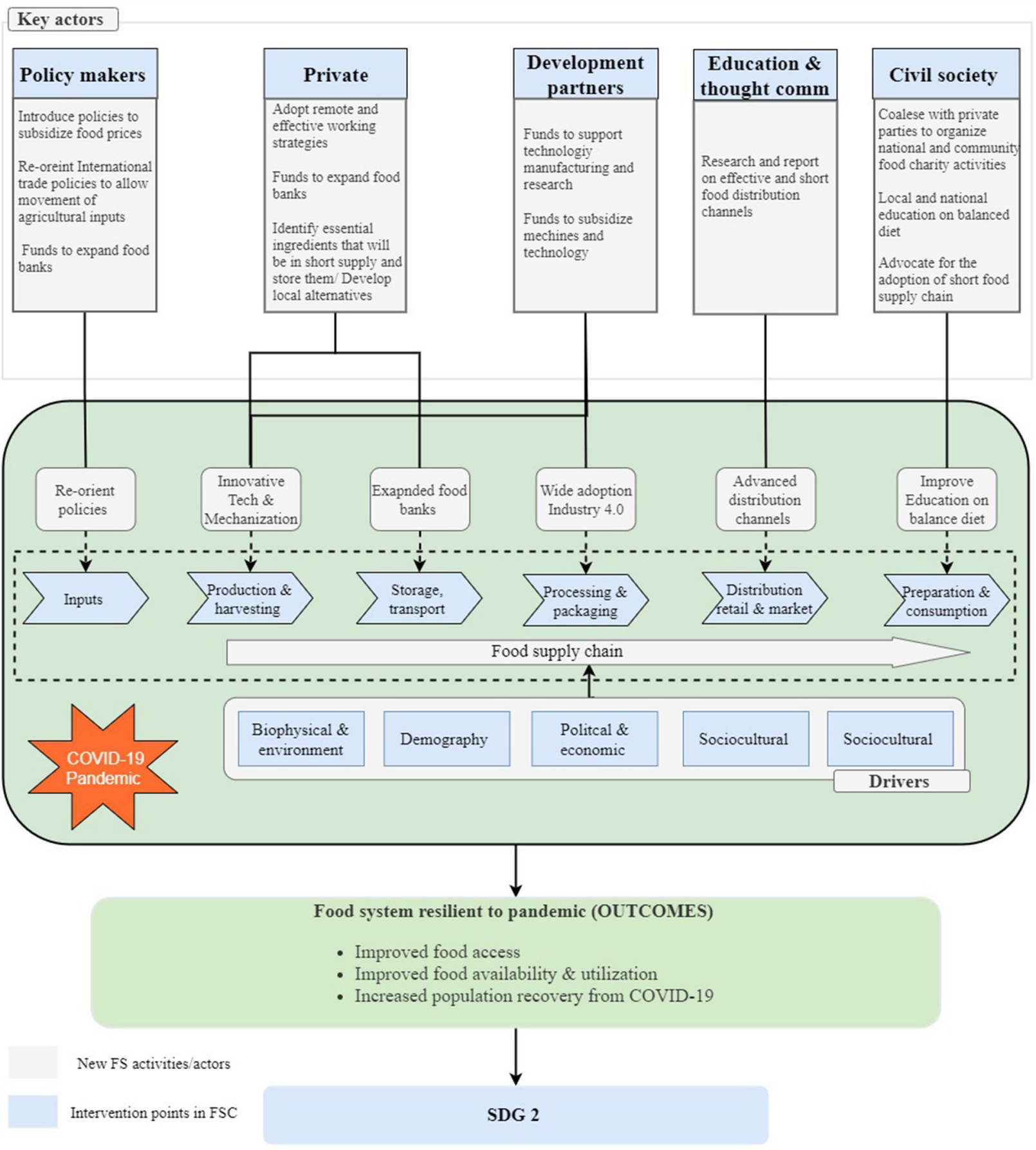

FIGURE 3 | A novel reconstructive framework for building resilience against COVID-19 pandemic.

sustainable manufacturing. It is imperative to understand that before these transformations can be achieved there is a need to identify tipping points or leverage points that will trigger actions. As presented by Galanakis (2020), Laborde et al. (2020), and Tamru et al. (2020), the current pandemic has offset and disrupted the food supply chain enormously. Therefore, given the nature and severity of the COVID-19 crisis, new adaptations are desired across the entire supply chain including recycle and reuse of waste, which minimizes physical contact but ensures that nutritional requirements are met (Aldaco et al., 2020). Also, the components of the supply chain present timely intervention points, which when prioritized could be enablers of business 
innovation. All things considered, now is the time to strategically redesign our supply chain to be both resilient and agile to shocks from the supply and demand perspective (Reardon and Swinnen, 2020).

Moving on, we present two narratives that represent a summary of the different proponents in the literature to address the COVID-19 food supply challenge. The first considers key innovation strategies that can be integrated into the current supply chain to drive long-term sustainable impact. Under this narrative, the main components include technologies and mechanization, education, advanced transport, and distribution channels and increased financial support and policies. These five components will significantly reduce food insecurity, nutritional insecurity, and food inequality associated with COVID-19. Table 9 presents an elaboration of the innovative components to be integrated into the current food system and the opportunities they present to ensure the resilience to COVID-19 pandemic is achieved.

Successfully integrating these five components into the current food system to build resilience against COVID-19 will require a multisectoral approach, which inadvertently disregards the convention silo-syndrome approach of tackling food system challenges. Hence, the second narrative focuses on the mobilization of key stakeholders in the food system. Table 10 outlines important insights into the role of key food system actors to build back better.

Populating the strategic components above on the food supply chain, we present Figure 3, a new transformational model for building food system resilience during the COVID19 pandemic. The transformational model can be adopted by the global food system initiative to guide their action plans to achieve healthy sustainable diets and circular and sustainable manufacturing. The important aspects of the framework are that (1) it highlights areas of technological adaptions to improve production, as well as distribution; (2) it identifies new routes to share light on education about a balanced diet and the inclusion of food commodities or ingredients that provide the necessary nutrients that enhance the immune system; and (3) maps out an improved and more efficient distribution channels of food items.

The authors hope that the framework presented will reorient future food system initiative by providing an opportunity for them to identify tipping points to implement their actions. The adoption of the proposed framework will not only enable food systems to build resilience not only in the current context but also in future pandemics that have not yet been envisaged. Ultimately, weaknesses within the food system can be eradicated as we continue to build capacities within our food system.

It is important to mention that initiatives such as the WFP have already responded to the pandemic with emergency response programs in African countries such as Ghana, Democratic Republic of Congo, and Syria. Although the efforts are laudable, moving forward, the global community ought to pursue food system transformation in a coordinated manner considering the threats of COVID-19 on food security. Failure to act now could prolong the achievability of the "zero hunger" agenda by 2030 .

\section{CONCLUSION}

The present study was designed to assess the contributions of global FSI in addressing food system challenges. Indeed, considerable efforts are being made by FSI to address multiple food system concerns ranging from environment, inequity, nutritional insecurity, to food insecurity. Contrarily, the analysis presented revealed that significant attention is given by FSIs to tackle nutritional insecurity. As a result, it is critical for FSIs to also adopt a systemic approach that considers all dimensions of food system concerns.

Another significant finding was the compounded impact of COVID-19 on food system challenges. The mappedout COVID-19 impact shows disruptions that heightened malnutrition and food inequality and inequity and calls for the reconstruction of the resilience pathways for food systems. The proposed reflective reconstruction framework provides a pathway toward new paradigm. First, it highlights domains in the food value chain for technological adaptations that ensure efficient food production and distribution; second, it identifies opportunities to intensify education on sustainable consumption patterns. This covers areas around balanced diet and the inclusion of food ingredients that provide the necessary nutrients and, finally, mapped out an improved and more efficient distribution channels that promote food safety. Additionally, the result enhances our understanding of the role of key stakeholders and leverage points within the supply chain to implement strategic proponents for transformation. A careful consideration of the framework presented will reorient future FSIs by providing not only an opportunity for them to identify tipping points in the value chain but also key strategic proponents that could be integrated into their action plans.

\section{AUTHOR CONTRIBUTIONS}

Conceptualization was done by EK and PA wrote initial draft with inputs from EK. EK reviewed and edited the manuscript. Both authors read and approved the final manuscript.

\section{FUNDING}

Funds for open access publication fee was provided by the Department of Biological and Agricultural Engineering Department, University of Arkansas, Fayetteville.

\section{ACKNOWLEDGMENTS}

The authors are grateful to the Department of Biological and Agricultural Engineering Department for supporting the work. 


\section{REFERENCES}

Abarca-Gómez, L., Abdeen, Z. A., Abdul Hamid, Z., Abu-Rmeileh, N. M., Acosta-Cazares, B., Acuin, C., et al. (2017). Worldwide trends in bodymass index, underweight, overweight, and obesity from 1975 to 2016: a pooled analysis of 2416 population-based measurement studies in 1289 million children, adolescents, and adults. Lancet. 390, 2627-2642. doi: 10.1016/S0140-6736(17)32129-3

Achicanoy, H. A. E., Patricia, Á., Christophe, B., Prager, S. D., Lea, L., and Camila, B. (2019). Sustainable Food Systems Global Index, I.C.f.T. Agriculture. Boston, MA: Harvard Dataverse. doi: 10.7910/DVN/GYEG59

Acuto, M. (2013). The new climate leaders? Rev. Int. Stud. 2013, 835-857. doi: $10.1017 /$ S0260210512000502

Ahmed, S., Downs, S. M., Yang, C., Chunlin, L., Ten Broek, N., and GhoshJerath, S. (2020). Rapid tool based on a food environment typology framework for evaluating effects of the COVID-19 pandemic on food system resilience. Food Security 12, 773-778. doi: 10.1007/s12571-02001086-z

Akkerman, R., Farahani, P., and Grunow, M. (2010). Quality, safety and sustainability in food distribution: a review of quantitative operations management approaches and challenges. OR Spectr. 32, 863-904. doi: 10.1007/s00291-010-0223-2

Aldaco, R., Hoehn, D., Laso, J., Margallo, M., Ruiz-Salmon, J., Cristobal, J., et al. (2020). Food waste management during the COVID-19 outbreak: a holistic climate, economic and nutritional approach. Sci. Total Environ. 742:140524. doi: 10.1016/j.scitotenv.2020.140524

Altieri, M. A., and Nicholls, C. I. (2020). Agroecology and the reconstruction of a post-COVID-19 agriculture. J. Peasant Stud. 47, 881-898. doi: 10.1080/03066150.2020.1782891

America, L., and Fund, R. (2016). Private Sector Peer Learning: Partnership Profiles Feed the Future (Washington, DC: Feed the Future), 1-2.

Amjath-Babu, T. S., Krupnik, T. J., Thilsted, S. H., and McDonald, A. J. (2020). Key indicators for monitoring food system disruptions caused by the COVID-19 pandemic: insights from Bangladesh towards effective response. Food Security 12, 761-768. doi: 10.1007/s12571-020-01083-2

Amundson, R., Berhe, A. A., Hopmans, J. W., Olson, C., Sztein, A. E., and Sparks, D. L. (2015). Soil science. Soil and human security in the 21 st century. Science 348:1261071. doi: $10.1126 /$ science. 1261071

Auernhammer, H. (2001). Precision farming-the environmental challenge. Comput. Electron. Agri. 30, 31-43. doi: 10.1016/S0168-1699(00) 00153-8

BCFN, MUFFP. (2018). Food \& Cities. The Role of Cities for Achieving the Sustainable Development Goals (Milan), 169. Available online at: https://www. barillacfn.com/it/

Beal, T., Massiot, E., Arsenault, J. E., Smith, M. R., and Hijmans, R. J. J. P. O. (2017). Global trends in dietary micronutrient supplies and estimated prevalence of inadequate intakes. PLoS ONE 12:e0175554. doi: 10.1371/journal.pone.0175554

Beddington, S. J. (2011). The future of food and farming. Int. J. Agri. Manag. 1, 2-6. doi: 10.22004/ag.econ.149777

Belanger, M. J., Hill, M. A., Angelidi, A. M., Dalamaga, M., Sowers, J. R., and Mantzoros, C. S. (2020). Covid-19 and disparities in nutrition and obesity. $N$ Engl J Med. 383:e69. doi: 10.1056/NEJMp2021264

Béné, C. (2020). Resilience of local food systems and links to food security - a review of some important concepts in the context of COVID-19 and other shocks. Food Security 12, 805-822. doi: 10.1007/s12571-020-01076-1

Béné, C., Oosterveer, P., Lamotte, L., Brouwer, I. D., Haan, S. D., Prager, S. D., et al. (2019a). When food systems meet sustainability - current narratives and implications for actions. World Dev. 113, 116-130. doi: 10.1016/j.worlddev.2018.08.011

Béné, C., Prager, S. D., Achicanoy, H. A. E., Toro, P. A., Lamotte, L., Bonilla, C., et al. (2019b). Global map and indicators of food system sustainability. Sci. Data 6:279. doi: 10.1038/s41597-019-0301-5

Bizikova, L., Jungcurt, S., McDougal, K., and Tyler, S. (2020). How can agricultural interventions enhance contribution to food security and SDG 2.1? Glob. Food Security 26:100450. doi: 10.1016/j.gfs.2020.100450

Bortoletti, M., and Lomax, J. (2019). Collaborative Framework for Food Systems Transformation. A Multistakeholder Pathway for Sustainable Food Systems. UN environment. ISBN (Nairobi), 978-92.
Briggs, L. (2016). Evaluation Team Leader, Patricia Vondal, Senior Evaluation Specialist, Charu Vijayakumar, Evaluation Specialist, Michael Maxey, et al. Feed the Future Global Performance Evaluation Report (Washington, DC: Dexis Consulting Group Contact).

Candel, J. J. L. (2018). Diagnosing integrated food security strategies. Wageningen J. Life Sci. 84, 103-113. doi: 10.1016/j.njas.2017.07.001

Candel, J. J. L. (2019). What's on the menu? A global assessment of MUFPP signatory cities ' food strategies. Agroecol. Sustain. Food Syst. 2019, 1-28. doi: 10.1080/21683565.2019.1648357

Cattivelli, V., and Rusciano, V. (2020). Social innovation and food provisioning during covid-19: the case of urban-rural initiatives in the Province of Naples. Sustainability 12:4444. doi: 10.3390/su12114444

Dantsis, T., Douma, C., Giourga, C., Loumou, A., and Polychronaki, E. A. (2010). A methodological approach to assess and compare the sustainability level of agricultural plant production systems. Ecol. Indicat. 10, 256-263. doi: 10.1016/j.ecolind.2009.05.007

Davidson, K., Coenen, L., and Gleeson, B. (2019). A decade of C40: research insights and agendas for city networks. Glob. Pol. 10, 697-708. doi: 10.1111/1758-5899.12740

Devereux, S., Béné, C., and Hoddinott, J. (2020). Conceptualising COVID19's impacts on household food security. Food Security 12, 769-772. doi: 10.1007/s12571-020-01085-0

D’Odorico, P., Carr, J. A., Davis, K. F., Dell'Angelo, J., and Seekell, D. A. (2019). Food inequality, injustice, and rights. BioScience 69, 180-190. doi: 10.1093/biosci/biz002

D’Odorico, P., Frankel Davis, K., Rosa, L., Carr, J. A., Chiarelli, D., Dell'Angelo, J., et al. (2018). The global food-energy-water nexus. Rev. Geophys. 56, 456-531. doi: 10.1029/2017RG000591

Dubuisson-Quellier, S., and Lamine, C. (2008). Consumer involvement in fair trade and local food systems: delegation and empowerment regimes. GeoJ. 73, 55-65. doi: 10.1007/s10708-008-9178-0

Duncan, T. (2016). Case study: taranaki farm regenerative agriculture. Pathways to integrated ecological farming. Land Restorat. Reclaim. Landscapes Sustain. Fut. 7, 271-287. doi: 10.1016/B978-0-12-801231-4.00022-7

El Bilali, H., Callenius, C., Strassner, C., and Probst, L. (2019). Food and nutrition security and sustainability transitions in food systems. Food Energy Security 8 , 1-20. doi: $10.1002 /$ fes 3.154

Elmadfa, I. (2005). Diet Diversification and Health Promotion. Basel; New York, NY: Karger. doi: 10.1159/isbn.978-3-318-01183-8

Fadele, O. K., Amusan, T. O., Ariyo, C. O., Afolabi, A. O., Onwuegbunam, N. E., and Oni, B. O. (2020). Sustainable agricultural mechanization in Nigeria in context of COVID-19. J. Sci. Res. Rep. 26, 53-59. doi: $10.9734 / \mathrm{jsrr} / 2020 / \mathrm{v} 26 \mathrm{i} 730284$

FAO (2014). Second International Conference on Nutrition (ICN2): Conference Outcome Document, in Rome (Rome).

FAO (2016). Influencing Food Environment for Healthy Diet. Rome: Italy Food and Agricultural Organization of the United Nations.

FAO, UNICEFW, WHO, and IFAD (2019). The State of Food Security and Nutrition in the World 2019: Safeguarding Against Economic Slowdowns and Downturns. Rome: FAO.

Farrell, F. P., Marie Thow, A., Tutuo Wate, J., Nonga, N., Vatucawaqa, P., Brewer, T., et al. (2020). COVID-19 and Pacific food system resilience: opportunities to build a robust response. Food Security 12, 783-791. doi: 10.1007/s12571-020-01087-y

Feenstra, G., Jaramillo, C., McGrath, S., and Grunnell, A. N. (2005). Proposed Indicators for Sustainable Food Systems. Portland, OR: Ecotrust.

Fluck, R. C. (2012). Energy in Farm Production. Amsterdam: Elsevier.

Galanakis, C. M. (2020). The food systems in the era of the coronavirus (COVID19) pandemic crisis. Foods. 9:523. doi: 10.3390/foods 9040523

Geissler, C., and Powers, H. J. (2017). Human Nutrition. Oxford: Oxford University Press.

Gil, J. D. B., Reidsma, P., Giller, K., Todman, L., Whitmore, A., and van Ittersum, M. (2019). Sustainable development goal 2: improved targets and indicators for agriculture and food security. Ambio 48, 685-698. doi: 10.1007/s13280-018-1101-4

Gralak, S., Spajic, L., Blom, I., El Omrani, O., Bredhauer, J., Uakkas, S., et al. (2020). COVID-19 and the future of food systems at the UNFCCC. Lancet 4, e309-e311. doi: 10.1016/S2542-5196(20)30163-7 
Haddad, L., Hawkes, C., Webb, P., Thomas, S., Beddington, J., Waage, J., et al. (2016). A new global research agenda for food. Nature 540:30. doi: $10.1038 / 540030 \mathrm{a}$

Hamukwala, P., et al. (2012). Improved seed variety value chains in Zambia: a missed opportunity to improve smallholder productivity. Afri. J. Agri. Res. 7, 4803-4818. doi: 10.5897/AJAR12.527

Harris, J., Depenbusch, L., Ahmad Pal, A., Madhavan Nair, R., Ramasamy, S. (2020). Food system disruption: initial livelihood and dietary effects of COVID-19 on vegetable producers in India. Food Security 12, 841-851. doi: 10.1007/s12571-020-01064-5

Hathaway, M. D. (2016). Agroecology and permaculture: addressing key ecological problems by rethinking and redesigning agricultural systems. J. Environ. Stud. Sci. 6, 239-250. doi: 10.1007/s13412-015-0254-8

Hatt, S., Artru, S., Brédart, D., Lassois, L., Francis, F., Haubruge, E., et al. (2016). Towards sustainable food systems: the concept of agroecology and how it questions current research practices. A review. Biotechnol. Agron. Soc. Environ. 20, 215-224. doi: 10.25518/1780-4507.12997

Hawkes, C., and Ruel, M. T. (2011). "Value chains for nutrition," in Paper Presented at Conference Leveraging Agriculture for Improving Nutrition and Health. New Delhi.

Henry, R. (2020). Innovations in agriculture and food supply in response to the COVID-19 pandemic. Mol. Plant 13, 1095-1097. doi: 10.1016/j.molp.2020.07.011

HLPE (2017). Nutrition and Food Systems. A Report by the High Level of Experts on Food Security and Nutrition of the Committee on World Food Security. Rome.

Hobbs, J. E. (2020). Food supply chains during the COVID-19 pandemic. Can. J. Agri. Econ. 2020:cjag.12237. doi: 10.1111/cjag.12237

Hugenschmidt, C. E. (2016). Type 2 Diabetes, obesity, and risk for dementia: recent insights into brain insulin resistance and hypometabolism. Curr. Behav. Neurosci. Rep. 3, 293-300. doi: 10.1007/s40473-016-0093-2

Husain, S., and Agamile, G. (2020). Economic and Food Security Implications of the COVID-19 Outbreak. Rome: World Food Programme. Available online at: https://reliefweb.int/sites/reliefweb.int/files/resources/WFP-0000117420.pdf

Irani, Z., Sharif, A. M., Lee, H., Aktas, E., Topaloglu, Z., van’t Wout, T., et al. (2018). Managing food security through food waste and loss: small data to big data. Comput. Operat. Res. 98, 367-383. doi: 10.1016/j.cor.2017.10.007

Ivanov, D., and Dolgui, A. (2020). Viability of intertwined supply networks: extending the supply chain resilience angles towards survivability. A position paper motivated by COVID-19 outbreak. Int. J. Product. Res. 58, 2904-2915. doi: 10.1080/00207543.2020.1750727

Jurgilevich, A., Birge, T., Kentala-Lehtonen, J., Korhonen-Kurki, K., Pietikäinen, J., Saikku, L., et al. (2016). Transition towards circular economy in the food system. Sustainability 8:69. doi: 10.3390/su8010069

Kamilaris, A., Fonts, A., and Prenafeta-Bold?, F. X. (2019). The rise of blockchain technology in agriculture and food supply chains. Trends Food Sci. Technol. 91, 640-652. doi: 10.1016/j.tifs.2019.07.034

Kirchherr, J., D., Reike, and Hekkert, M. (2017). Conceptualizing the circular economy: an analysis of 114 definitions. Resourc. Conserv. Recycl. 127, 221-232. doi: 10.1016/j.resconrec.2017.09.005

Klassen, S., and Murphy, S. (2020). Equity as both a means and an end: lessons for resilient food systems from COVID-19. World Dev. 136:105104. doi: 10.1016/j.worlddev.2020.105104

Kumar, A., Padhee, A. K., and Kumar, S. J. F. S. (2020). How Indian agriculture should change after COVID-19. Food Sec. 12, 837-840. doi: 10.1007/s12571-020-01063-6

Kuyper, E. M., Engle-Stone, R., Arsenault, J. E., Arimond, M., Adams, K. P., and Dewey, K. G. (2017). Dietary gap assessment: an approach for evaluating whether a country's food supply can support healthy diets at the population level. Public Health Nutr. 20, 2277-2288. doi: 10.1017/S1368980017 001173

Laborde, D., Martin, M., Swinnen, J., and Vos, R. (2020). COVID-19 risks to global food security. Science. 369, 500-502. doi: 10.1126/science.abc4765

Lipinski, B., Hanson, C., Lomax, J., Kitinoja, L., Waite, R., and Searchinger, T. (2013). Reducing Food Loss and Waste. World Resources Institute Working Paper (Washington, DC: World Resource Institute). 1, 1-40.

Liu, X., Zhang, S., and Bae, J. (2017). The nexus of renewable energyagriculture-environment in BRICS. Appl. Energy 204, 489-496. doi: 10.1016/j.apenergy.2017.07.077
Macdiarmid, J. I., Kyle, J., Horgan, G. W., Loe, J. E., Fyfe, C., Johnstone, A., et al. (2011). Livewell: A Balance of Healthy and Sustainable Food Choices. World Wildlife Fund. 64.

Matson, P. A., Parton, W. J., Power, A. G., and Swift, M. J. (1997). Agricultural intensification and ecosystem properties. Science 277, 504-509. doi: $10.1126 /$ science.277.5325.504

McKee, M., and Stuckler, D. (2020). If the world fails to protect the economy, COVID-19 will damage health not just now but also in the future. Nat. Med. 26, 640-642. doi: 10.1038/s41591-020-0863-y

Moench-Pfanner, R., and Van Ameringen, M. (2012). The Global Alliance for Improved Nutrition (GAIN): a decade of partnerships to increase access to and affordability of nutritious foods for the poor. Food Nutr. Bullet. 33(4Suppl.3), S373-S380. doi: 10.1177/15648265120334S313

Molden, D., Oweis, T., Steduto, P., Bindraban, P., Hanjra, M. A., and Kijne, J. (2010). Improving agricultural water productivity: between optimism and caution. Agri. Water Manag. 97, 528-535. doi: 10.1016/j.agwat.2009.03.023

Mooney, P. (2017). Too Big to Feed: Exploring the Impacts of Mega-Mergers, Consolidation and Concentration of Power in the Agri-Food Sector. IPES-Food Report, Brussels. Available online at: http://www.ipes-food.org/

Mozaffarian, D. (2016). Dietary and policy priorities for cardiovascular disease, diabetes, and obesity: a comprehensive review. Circulation 133, 187-225. doi: 10.1161/CIRCULATIONAHA.115.018585

Murray, C. J. (2015). Choosing indicators for the health-related SDG targets. Lancet 386, 1314-1317. doi,: 10.1016/S.0140-6736(15)00382-7

New Zealand (2015). Ministry of Business, Innovation, and Employment, New Zealand's Internet Upgrade. Retrieved from: http://www.med.govt.nz/sectorsindustries/technology-communication/fastbroadband

Patel, R. (2009). Food sovereignty. J. Peasant Stud. 36, 663-706. doi: 10.1080/03066150903143079

Pérez-Escamilla, R., Cunningham, K., and Moran, V. H. (2020). COVID-19 and maternal and child food and nutrition insecurity: a complex syndemic. Wiley Online Library. 16:e13036. doi: 10.1111/mcn.13036

Pham, L. V., and Smith, C. (2014). Drivers of agricultural sustainability in developing countries : a review. Clim. Change 93, 326-341. doi: 10.1007/s10669-014-9494-5

Power, M., Doherty, B., Pybus, K., Pickett, K., Jackson, P., Holt, D., et al. (2020). COVID-19 has exposed inequalities in the UK food system : the case of UK food and poverty. Emerald Open Res. 2020, 1-27. doi: 10.35241/emeraldopenres.13539.1

$\mathrm{Pu}, \mathrm{M}$., and Zhong, Y. (2020). Rising concerns over agricultural production as COVID-19 spreads: lessons from China. Glob. Food Security 26:100409. doi: 10.1016/j.gfs.2020.100409

Ragasa, C., and Lambrecht, I. (2020). COVID-19 and the food system: setback or opportunity for gender equality? Food Security 12, 877-880. doi: 10.1007/s12571-020-01089-w

Rasul, G., and Thapa, G. B. (2004). Sustainability of ecological and conventional agricultural systems in Bangladesh: an assessment based on environmental, economic and social perspectives. Agri. Syst. 79, 327-351. doi: 10.1016/S0308-521X(03)00090-8

Reardon, T., Bellemare, M. F., and Zilberman, D. (2020). How COVID-19 May Disrupt Food Supply Chains in Developing Countries. IFPRI Book Chapters, 78-80. doi: 10.2499/p15738coll2.133762_17

Reardon, T., and Swinnen, J. (2020). "COVID-19 and Resilience Innovations in Food Supply Chains," in COVID-19 and Global Food Security, eds J. Swinnen, and J. McDermott (Washington, DC: International Food Policy Research Institute), 132-136. doi: 10.2499/p15738coll2.133762_30

Rosin, C., Stock, P., and Campbell, H. (2013). Food Systems Failure: The Global Food Crisis and the Future of Agriculture (London: Routledge). doi: $10.4324 / 9781849776820$

Rowan, N. J., and Galanakis, C. M. (2020). Unlocking challenges and opportunities presented by COVID-19 pandemic for cross-cutting disruption in agri-food and green deal innovations: Quo Vadis? Sci. Total Environ. 2020:141362. doi: 10.1016/j.scitotenv.2020.141362

Sabanayagam, C., Ezzati, M., Mallikharjuna Rao, M., Khalili, D., Lehtimaki, T., Hajifathalian, K., et al. (2016). Worldwide Trends in Diabetes Since 1980: A Pooled Analysis of 751 Population-Based Studies With 4.4 Million Participants.

Sanchez, P. A. (2020). Viewpoint: time to increase production of nutrient-rich foods. Food Pol. 2020:101843. doi: 10.1016/j.foodpol.2020.101843 
Savary, S., Akter, S., Almekinders, C., Harris, J., Korsten, L., Rötter, R., et al. (2020). Mapping disruption and resilience mechanisms in food systems. Food Security 12, 695-717. doi: 10.1007/s12571-020-01093-0

Schipanski, M. E., MacDonald, G. K., Rosenzweig, S., Jahi Chappell, M., Bennett, E. M., Bezner Kerr, R., et al. (2016). Realizing resilient food systems. BioScience 66, 600-610. doi: 10.1093/biosci/biw052

Seekell, D., Carr, J., Dell'Angelo, J., D’Odorico, P., Fader, M., Gephart, J., et al. (2017). Resilience in the global food system. Environ. Res. 12:25010. doi: 10.1088/1748-9326/aa5730

Sherwood, S., and Uphoff, N. (2000). Soil health: research, practice and policy for a more regenerative agriculture. Appl. Soil Ecol. 15, 85-97. doi: 10.1016/S0929-1393(00)00074-3

Shilomboleni, H. (2020). COVID-19 and food security in Africa: building more resilient food systems. AAS Open Res. 3:13078. doi: 10.12688/aasopenres.13078.1

Singh, S., Kumar, R., Panchal, R., and Tiwari, M. K. (2020). Impact of COVID-19 on logistics systems and disruptions in food supply chain. Int. J. Product. Res. 2020:1792000. doi: 10.1080/00207543.2020.1792000

Solon, M. M., Mink, P., Dernini, S., Bortoletti, M., and Lomax, J. (2018). The one planet sustainable food systems (SFS) programme as a multi-stakeholder platform for a systemic approach. Sustain. Diets Link. Nutr. Food Syst. 2018, 178-189. doi: 10.1079/9781786392848.0178

Stephens, E. C., Martin, G., Van Wijk, M., Timsina, J., and Snow, V. (2020). Editorial: impacts of COVID-19 on agricultural and food systems worldwide and on progress to the sustainable development goals. Agri. Syst. 183:102873. doi: 10.1016/j.agsy.2020.102873

Tamru, S., Hirvonen, K., and Minten, B. (2020). "Impacts of the COVID-19 Crisis on Vegetable Value Chains in Ethiopia," in COVID-19 and Global Food Security, eds J. Swinnen, and J. McDermott (Washington, DC: International Food Policy Research Institute), 81-83. doi: 10.2499/p15738coll2.133762_18

Thompson, J., and Blank, S. (2000). Harvest mechanization helps agriculture remain competitive. California Agri. 54, 51-56. doi: 10.3733/ca.v054n03p51

Tscharntke, T., Klein, A. M., Kruess, A., Steffan-Dewenter, I., and Thies, C. (2005). Landscape perspectives on agricultural intensification and biodiversity-ecosystem service management. Ecol. Lett. 8, 857-874. doi: $10.1111 / \mathrm{j} .1461-0248.2005 .00782 . x$

Valdramidis, V. P., Argyropoulos, D., Ahrne, L., Chen, J., Cullen, P. J., Cummins, E., et al. (2020). Current Research in Food Science Perspectives from CO $\mathrm{p}$ RE : how COVID-19 changed our food systems and food security paradigms. Curr. Res. Food Sci. 3, 166-172. doi: 10.1016/j.crfs.2020. 05.003

Van Cauwenbergh, N., Biala, K., Bielders, C., Brouckaert, V., Franchois, L., Garcia Cidad, V., et al. (2007). SAFE-a hierarchical framework for assessing the sustainability of agricultural systems. Agri. Ecosyst. Environ. 120, 229-242. doi: 10.1016/j.agee.2006.09.006

Van Doorn, A. M., and Bakker, M. M. (2007). The destination of arable land in a marginal agricultural landscape in South Portugal: an exploration of land use change determinants. Landscape Ecol. 22, 1073-1087. doi: 10.1007/s10980-007-9093-7

Venkatramanan, V., and Shah, S. (2019). Climate smart agriculture technologies for environmental management: the intersection of sustainability, resilience, well-being and development. Sustain. Green Technol. Environ. Manag. 2019, 29-51. doi: 10.1007/978-981-13-2772-8_2

Vermeulen, S. J., Campbell, B. M., and Ingram, J. S. I. (2012). Climate change and food systems. Ann. Rev. Environ. Resourc. 37, 195-222. doi: 10.1146/annurev-environ-020411-130608

Watts, M., Austin, K., Lawrence, S., Fernández, A., Doust, M., Alpert, J., et al. (2019). Adressing Food-Related Consumption-Based Emission in C40 Cities (Leeds: University of Leeds), 31.

West, P. C., Gerber, J. S., Engstrom, P. M., Mueller, N. D., Brauman, K. A., Carlson, K. M., et al. (2014). Leverage points for improving global food security and the environment. Science 345, 325-328. doi: 10.1126/science. 1246067

Windfuhr, M., and Jonsén, J. (2005). Food Sovereignty: Towards Democracy in Localized Food Systems (Bourton-on-Dunsmore: ITDG Publishing) doi: 10.3362/9781780441160. Retrieved from: http://www.ukabc.org/ foodsovereignty_itdg_fian_print.pdf

World Economic Forum (2019). Feeding the Future: Food Action Alliance Launch (Cologny: World Economic Forum).

World Economic Forum (2020). Incentivizing Food Systems Transformation.

Yancy, C. W. (2020). COVID-19 and African Americans. J. Am. Med. Assoc. 2020:6548. doi: 10.1001/jama.2020.6548

Zhang, S., Wang, S., Yuan, L., Liu, X., and Gong, B. (2020). The impact of epidemics on agricultural production and forecast of COVID19. China Agri. Econ. Rev. 2020:55. doi: 10.1108/CAER-04-20200055

Conflict of Interest: The authors declare that the research was conducted in the absence of any commercial or financial relationships that could be construed as a potential conflict of interest.

Publisher's Note: All claims expressed in this article are solely those of the authors and do not necessarily represent those of their affiliated organizations, or those of the publisher, the editors and the reviewers. Any product that may be evaluated in this article, or claim that may be made by its manufacturer, is not guaranteed or endorsed by the publisher.

Copyright (C) 2021 Agyemang and Kwofie. This is an open-access article distributed under the terms of the Creative Commons Attribution License (CC BY). The use, distribution or reproduction in other forums is permitted, provided the original author(s) and the copyright owner(s) are credited and that the original publication in this journal is cited, in accordance with accepted academic practice. No use, distribution or reproduction is permitted which does not comply with these terms. 